\title{
Fungicide and Cultivar Effects on Sudden Death Syndrome and Yield of Soybean
}

Yuba R. Kandel, Department of Plant Pathology and Microbiology, Iowa State University, Ames 50011; Kiersten A. Wise, Department of Botany and Plant Pathology, Purdue University, West Lafayette, IN 47907; Carl A. Bradley, Department of Crop Sciences, University of Illinois, Urbana 61801; Martin I. Chilvers, Department of Plant, Soil and Microbial Sciences, Michigan State University, East Lansing 48824; Albert U. Tenuta, Ontario Ministry of Agriculture, Food and Rural Affairs, Ridgetown, ON NOP2C0, Canada; and Daren S. Mueller, Department of Plant Pathology and Microbiology, Iowa State University, Ames

\begin{abstract}
Kandel, Y. R., Wise, K. A., Bradley, C. A., Chilvers, M. I., Tenuta, A. U., and Mueller, D. S. 2016. Fungicide and cultivar effects on sudden death syndrome and yield of soybean. Plant Dis. 100:1339-1350.

The effect of fungicides on severity of sudden death syndrome (SDS; caused by Fusarium virguliforme), plant establishment, and soybean yield was evaluated in 12 field experiments conducted in Illinois, Indiana, Iowa, Michigan, and Ontario in 2013 and 2014. Two soybean cultivars that differed in susceptibility to SDS were planted in fields with a history of SDS or with artificial augmentation of $F$. virguliforme. Efficacy of seed, in-furrow, and foliar-applied fungicides was assessed. SDS levels varied across locations and years. Fluopyram applied on the seed or in-furrow reduced foliar disease index maximum up to $95 \%$ in 5 of the 12 experiments. In three experiments with significant $(P<0.10)$ treatment effect, fluopyram seed treatment improved yields up to $11 \%$ compared with the base seed treatment comprising

prothioconazole + penflufen + metalaxyl and clothianidin + Bacillus fir mus. Meta-analysis also indicated that the fluopyram seed treatment and in-furrow application were effective at reducing SDS and increasing yield relative to the control; however, the baseline disease influenced the yield and disease response to fungicide treatments. Treatment effect was not significant when disease pressure was low. The concentration of $F$. virguliforme DNA in soybean roots, measured by a specific real-time quantitative polymerase chain reaction assay, was not different among fungicide treatments in 9 of 10 experiments. Moderately resistant cultivars had less disease than susceptible cultivars, indicating that resistant cultivars in combination with fluopyram seed treatment or in-furrow application could provide effective management of SDS.
\end{abstract}

Sudden death syndrome (SDS), caused by Fusarium virguliforme O'Donnell \& T. Aoki (Aoki et al. 2003), is one of the most important diseases of soybean (Glycine $\max$ (L.) Merr.), in the United States and Canada (Wrather et al. 2010). SDS may result in minimal to more than $80 \%$ yield loss, depending upon cultivar, time of disease onset, and severity (Roy et al. 1997). Luo et al. (2000) reported that an increase of one unit of foliar disease index (FDX) resulted in yield loss of 18 to $29 \mathrm{~kg} / \mathrm{ha}$. Annual yield loss estimates due to SDS for 10 years between 2005 and 2014 in the United States ranged from 0.54 million metric tons ( $\mathrm{t}$ ) (in 2005) to 1.90 million $\mathrm{t}$ (in 2010), with an average of 0.92 million t (Bradley et al. 2014; Koenning and Wrather 2010; Wrather and Koenning 2006). SDS was first discovered in 1971 in Arkansas (Hirrel 1983). Since then, the disease has become more widespread in major soybean-growing regions of the United States and Ontario, Canada (Anderson and Tenuta 1998; Hartman et al. 2015a; Leandro et al. 2012). The increasing range and intensity of SDS indicates an urgent need to find sustainable management solutions for this disease.

$F$. virguliforme colonizes soybean root tissue and produces phytotoxins, primarily FvTox1, that cause foliar symptoms (Brar et al. 2011; Pudake et al. 2013). Typical foliar symptoms include interveinal chlorotic mottling and necrosis, premature defoliation, and pod abortion (Hartman et al. 2015b; Roy et al. 1997). Foliar symptoms may occur any time in the season but typically develop around R3

Current address of C. A. Bradley: Department of Plant Pathology, University of Kentucky Research \& Education Center, Princeton 42445.

Corresponding author: D. Mueller; E-mail: dsmuelle@iastate.edu

*The $\boldsymbol{e}$-Xtra logo stands for "electronic extra" and indicates that three supplementary tables are published online.

Accepted for publication 25 February 2016.

http://dx.doi.org/10.1094/PDIS-11-15-1263-RE

(C) 2016 The American Phytopathological Society growth stage (Fehr et al. 1971). With favorable environmental conditions for disease, foliar symptoms can progress rapidly in susceptible cultivars.

Although management through genetic resistance is the preferred and most cost-effective management strategy, breeding for SDS resistance is challenging because of the quantitative nature of disease resistance, lack of complete resistance sources, and significant influence of the environment on disease development. Several cultural management strategies such as crop rotation (Rupe et al. 1997), tillage (Wrather et al. 1995), planting date (Hershman et al. 1990; Wrather et al. 1995), and soybean cyst nematode (SCN) management (Westphal et al. 2014; Xing and Westphal 2006) can reduce disease but effects of these practices on SDS can be inconsistent (Kolander et al. 2012; Xing and Westphal 2009) and no single practice can completely manage SDS. Fungicides are used to complement host resistance and are effective against many plant pathogens in soybean, including Fusarium spp. Several commercial fungicides are registered for soybean and are effective against several species of Fusarium (Chala et al. 2003; Ellis et al. 2011; Paul et al. 2008; Yoshida et al. 2008). Weems et al. (2015) tested several fungicides as seed treatments, including azoxystrobin, Bacillus pumilus GB34, fludioxonil, mefenoxam or metalaxyl, prothioconazole, thiophanate-methyl, and thiophanate-methyl + pyraclostrobin, trifloxystrobin + metalaxyl in multiple combinations, and none consistently affected $F$. virguliforme or SDS. Despite the lack of reported efficacy against $F$. virguliforme, fungicides are still commonly promoted for use in soybean, and farmers are interested in determining whether applications could reduce the impact of SDS. Foliar fungicides have not traditionally been considered for use against SDS, primarily because labeled fungicides are locally systemic and not able to move basipetally to where infection and fungal growth occur. In-furrow applications to soybean have been compared with seed treatments for control of Phytophthora spp. (Guy et al. 1989) but adoption of this practice is reliant on farmers having the appropriate equipment. In-furrow fungicide applications recently have been touted in sales marketing campaigns as enhancing seedling vigor and providing additional broadspectrum protection from soilborne pathogens rather than relying on fungicide seed treatment alone. These applications are relatively 
new in soybean production, and the efficacy of labeled products against many fungi, including $F$. virguliforme, is currently unknown. In this study, we tested different application strategies, including infurrow and foliar application, with the products that are currently labeled and promoted against many soybean diseases.

The fungicide fluopyram (ILeVO; Bayer CropScience, Research Triangle Park, NC) was registered in December 2014 for the treatment of soybean seed to manage SDS. Fluopyram is a succinate dehydrogenase inhibitor (Fungicide Resistance Action Committee group 7). Succinate dehydrogenase is an essential enzyme in the respiratory pathway, and inhibition of the enzyme blocks energy production, which affects spore germination and germ tube elongation (Veloukas and Karaoglanidis 2012). Fluopyram is also the active ingredient (a.i.) used in the Bayer CropScience Luna product line. For example, Luna Privilege, a fungicide registered for fruit diseases, is used to manage several fungal soil and seedborne diseases of horticultural and row crops (Fought et al. 2011; Labourdette et al. 2010; Meredith 2012; Proffer et al. 2013; Veloukas and Karaoglanidis 2012). The efficacy of fluopyram against SDS and its affect on soybean yield under a wide range of environment and management regimes has not been well documented. The objective of this research was to examine the effect of fungicide rate, application method, and timing on soybean establishment, root rot, SDS severity, and yield.

\section{Materials and Methods}

Field experiments. Field experiments in the United States were established in Illinois, Indiana, Iowa, and Michigan and in Canada in the province of Ontario in 2013 and 2014, for a total of 12 experiments. Two separate field experiments were completed each year in Ontario. Details of field experiments, including locations, soybean cultivars, and treatment combinations, are summarized in Tables 1 and 2.

Field experiments were arranged in a split plot with completely randomized design for the main-plot factor and randomized complete block design for split-plot factors, with four replications. Soybean cultivars were the main plot and fungicide treatments were the subplot factors. In each experiment, all fungicide treatments were evaluated on two soybean cultivars that differed in susceptibility to SDS, based on scores provided by the seed companies. Cultivars differed across locations and years and selection was based on availability and adaptation to the site (Table 1). In total, 16 fungicide treatments were evaluated. In 2013, 13 fungicide treatments with different rates, application methods, and timings of 5 fungicide products included fluopyram (ILeVO and Luna Privilege; Bayer CropScience), pyraclostrobin (Headline EC; BASF, Research Triangle Park, NC), pyraclostrobin + fluxapyroxad (Priaxor; BASF), and trifloxystrobin + prothioconazole (Stratego YLD; Bayer CropScience). The control was a base seed treatment with prothioconazole + penflufen + metalaxyl (EverGol Energy, $0.019 \mathrm{mg}$ a.i./seed; Bayer CropScience), metalaxyl (Allegiance, $0.02 \mathrm{mg}$ a.i./seed; Bayer CropScience), and clothianidin + B. firmus (Poncho/VOTiVO, $0.13 \mathrm{mg}$ a.i./seed; Bayer CropScience). Pro-Ized red seed colorant (Gustafson LLC, Plano, TX) and finisher (Peridiam Precise 1010; Bayer CropScience) were added on treated seed at the rate of 32.6 and $65 \mathrm{ml} / 100 \mathrm{~kg}$ of seed, respectively. Seed treatments were applied with a Hege bowl seed treater (Wintersteiger, Salt Lake City, UT). All other treatments (Table 2) were applied in addition to the base seed treatment. Fungicide application methods included seed treatment and in-furrow applications at planting and foliar applications at stages V3, V6, R1, and R3 (Fehr et al. 1971). In 2014, all R1 and R3 foliar applications were removed from the experiment and in-furrow pyraclostrobin + fluxapyroxad and foliar applications of fluopyram and pyraclostrobin + fluxapyroxad at V3 were added, for a total of 9 treatments (Table 2). Some of the foliar applications were excluded in the second year of the study because foliar application was not consistently effective at reducing SDS in 2013 field experiments. Experiments were placed in fields with a recent history of SDS. Soybean was planted from early May to early June. Plots differed across sites and consisted of four rows with $38.1-$ to $76.2-\mathrm{cm}$ spacing, and plot length ranged from 5.3 to $9.1 \mathrm{~m}$. Each plot was an experimental unit.

Preplant tillage was done to prepare the seed bed at all locations and years. The previous crop before the experiment was corn or soybean at all the sites, except at Highgate, ON in 2014, where wheat was grown in the previous year. Soil was artificially infested with $F$. virguliforme inoculum following a protocol described by de Farias Neto et al. (2006), except at Michigan and Ontario (Table 1). Inoculum was produced by using single-spore-derived local $F$. virguliforme isolates to colonize sterilized sorghum or oat grains. Infested grains were applied in-furrow with soybean seed at planting. Field plots in Illinois, Indiana, Michigan, and year two in Iowa were irrigated, whereas other experiments received natural precipitation only. Water was applied through drip irrigation in Illinois and Iowa and through overhead irrigation in Indiana and Michigan. All other agronomic practices were performed according to the typical soybean cultivation practices, including pre- and postemergence herbicide applications (Table 1).

All seed was treated as described above. In all locations except Michigan, in-furrow applications were made with a single nozzle banded over the top of the furrow that created a 5- to $10-\mathrm{cm}$ wide swath. In Michigan, the fungicide was applied over the top of the closed furrow with a single nozzle. Foliar applications were made using different sprayers and nozzles across the experiments. In Illinois, fungicides were applied using a $\mathrm{CO}_{2}$-pressurized backpack sprayer and 1.5-m handheld boom with four TJ-60 8002VS nozzle tips spaced $48 \mathrm{~cm}$ apart, which was calibrated to deliver 187 liters/ha at $276 \mathrm{kPa}$ of pressure. In Indiana, fungicide applications were applied using a $\mathrm{CO}_{2}$-pressurized backpack sprayer and 1.5 -m handheld boom fitted with four TJ-VS 8001 nozzles spaced $51 \mathrm{~cm}$ apart, which delivered 140 liters/ha at $275 \mathrm{kPa}$ of pressure. In Iowa, foliar applications were made with a self-propelled small research plot sprayer consisting of six flat-fan nozzles (Teejet 11015 XR) spaced $51 \mathrm{~cm}$ apart and sprayed at a pressure of $241 \mathrm{kPa}$, which delivered 140 liters/ha. In Michigan, fungicides were applied with a handheld spray boom pressurized with $\mathrm{CO}_{2}$ at $276 \mathrm{kPa}$. The spray boom consisted of six nozzles (Teejet $11001 \mathrm{VS}$ ) spaced $51 \mathrm{~cm}$ apart and was calibrated to apply 140 liters/ha. In Ontario, foliar applications were applied using a $\mathrm{CO}_{2}$-pressurized backpack sprayer fitted with a 120 -cm handheld boom with four 8002 VS TeeJet nozzles spaced at $30 \mathrm{~cm}$ apart and sprayed at $241 \mathrm{kPa}$ of pressure, which delivered 140 liters/ha.

Plant population data collection. Number of plants were counted in 3.0 to $6.1 \mathrm{~m}$ on one to two center rows of each plot at the V2 or V3 growth stage.

Root rot assessment and quantification of $\boldsymbol{F}$. virguliforme. At $\mathrm{V} 2$ to $\mathrm{V} 3$ growth stage, 12 plants per plot from outer rows were removed with a shovel, roots were gently washed, and root rot severity was estimated visually as the percentage of root area with root lesions and brown discoloration. Root rot and quantitative polymerase chain reaction (qPCR) analyses were conducted at the $\mathrm{V} 2$ to $\mathrm{V} 3$ growth stage to examine whether seed treatment or in-furrow application affected initial $F$. virguliforme population in the root and root rot severity and to determine how that related to later-season SDS foliar symptoms. For qPCR analysis, roots were oven dried at $50^{\circ} \mathrm{C}$ for $24 \mathrm{~h}$ or dried on a greenhouse bench for 5 to 7 days. Dried roots were ground by plot in a Thomas Wiley mini mill (3383-L40; Thomas Scientific, Swedesboro, NJ) using a screen with $0.40-\mathrm{mm}$ pores (mesh size 40). Root powder was homogenized and 80 to $100 \mathrm{mg}$ was subsampled in a $2-\mathrm{ml}$ self-lock autoclaved microcentrifuge tube. Total DNA extraction was performed using the DNeasy plant Mini Kit (Qiagen Inc., Germantown, MD) according to the manufacturer's recommendations, with slight modifications. Modifications included the addition of 600 to $800 \mu \mathrm{l}$ of the lysis buffer to each tube rather than $400 \mu \mathrm{l}$, and the tubes were incubated overnight at ambient temperature. DNA quantity was determined using a NanoDrop 1000 spectrophotometer (Thermo Fisher Scientific, Wilmington, DE) and normalized to $10 \mathrm{ng} / \mu \mathrm{l}$ for each sample.

Quantification of $F$. virguliforme DNA was performed using a $F$. virguliforme-specific real-time qPCR assay using specific primer pairs F 5'-GTAAGTGAGATTTAGTCTAGGGTAGGTGAC-3' and 
R 5'-GGGACCACCTACCCTACACCTACT-3' and probe 5'-6FAMTTTGGTCTAGGGTAGGCCG-/MGBNFQ/-3'(Wang et al. 2015). Real-time qPCR was performed in a total volume of $20 \mu$ l containing $5 \mu \mathrm{l}$ of test DNA with two technical replicates. Amplifications were performed on Bio-Rad iQ5/iCycler iQ5 optical system software (version 2.1; Bio-Rad Laboratories, Inc., Hercules, CA). The PCR mix and thermal conditions were conducted as previously described (Wang et al. 2015). Each PCR plate contained the nontemplate control and serial dilutions of the positive control (DNA of $F$. virguliforme isolate Mont1) at $1 \mathrm{ng} / \mu \mathrm{l}, 100 \mathrm{pg} / \mu \mathrm{l}, 10 \mathrm{pg} / \mu \mathrm{l}, 1 \mathrm{pg} / \mu \mathrm{l}, 100 \mathrm{fg} / \mu \mathrm{l}, 10 \mathrm{fg} / \mu \mathrm{l}$, and $1 \mathrm{fg} / \mu \mathrm{l}$. Standard curves were generated by plotting the cycle threshold number against the base ${ }_{10} \log$ of the initial concentration of the standard DNA. The resulting curve was used to estimate initial quantity of $F$. virguliforme DNA in the test samples.

Foliar disease assessment. Foliar symptoms of SDS were assessed between the R5 and R7 growth stages (Table 2). Foliar disease incidence (FDI) was visually estimated as percentage of SDSsymptomatic plants in the middle two rows of the plot. Foliar disease severity (FDS) was estimated on a 0 -to- 9 scale (where $0=$ no disease and $9=$ premature death of the plant) following a scale published previously (Gibson et al. 1994; Kandel et al. 2015). The FDX was calculated using the formula FDX $=$ FDI $\times$ FDS/9. SDS was confirmed by splitting stems of a few plants with foliar symptoms from border rows in all experiments and examining the diagnostic symptoms of gray-brown discoloration in the lower cortex of the plant.

Yield data. The center two rows were mechanically harvested for yield at harvest maturity (R8), which was late September to midNovember (Table 2). Grain moisture was recorded and yields were adjusted to $13 \%$ moisture. Yield data were not collected from Boone, IA in 2013 because experimental plots were bulk harvested by mistake.

Analysis of variance and correlation coefficients. Data were analyzed in SAS (version 9.3; SAS Institute Inc., Cary, NC). Analysis of variance (ANOVA) was performed using PROC GLIMMIX for plant population, root rot severity, FDX, grain yield, and $F$. virguliforme DNA concentration. Separate ANOVA was performed for each experiment because specific fungicide treatments and cultivars differed across sites and years. Cultivars and fungicide were treated as fixed factors and replication within cultivar was used as a random factor. Replication within cultivar was used as an error term to test the effect of cultivar and the residual error was used to test the effect of fungicide treatments and fungicide-cultivar interaction. Mean separations were performed using Fisher's protected least significant difference at $\alpha=0.10$. Cultivars were combined to present the treatment effect because cultivar-treatment interaction was not significant in most cases. Pearson correlation coefficients (PROC CORR) were generated to determine the relationships among root rot, FDX, and grain yield.

Quantitative synthesis of fluopyram efficacy based on metaanalysis. Because ANOVA for individual field experiment showed inconsistent results across the experiments on the efficacy of fungicide treatments, we also performed multivariate random effect model meta-analysis to evaluate the overall efficacy of fungicide treatments relative to the control (Madden and Paul 2011). Meta-analysis was performed using a standard factorial ANOVA approach in PROC GLIMMIX in SAS, version 9.4. In each experiment site, fungicide treatments were applied to two cultivars; each cultivar was considered as a separate study for the meta-analysis. Study main effect and study-treatment interaction were considered as random effects and treatment was considered as a fixed effect in the model. Treatment summaries and means for each treatment $\left(y_{i}\right)$, including the control (means from base seed treatment), from each individual study were used to perform the meta-analysis instead of analyzing contrasts $\left(z_{i}\right)$, which is a more commonly used approach for meta-analysis (Piepho 2014; Piepho et al. 2012). Piepho et al. (2012) illustrated that a factorial ANOVA approach using treatment summaries provide results similar to the baseline contrast-based approach of meta-analysis.

Table 1. Experiment locations, soybean cultivars, and additional field activities performed in the experiments carried out in the states of Iowa, Illinois, Indiana, and Michigan and in Ontario, Canada in 2013 and 2014

\begin{tabular}{|c|c|c|c|c|c|c|c|c|c|}
\hline \multirow[b]{2}{*}{ Loc, DOPu } & \multirow[b]{2}{*}{ Cult $^{v}$} & \multicolumn{2}{|c|}{ SDS ratings } & \multirow[b]{2}{*}{ Hrvw $^{\text {w }}$} & \multirow[b]{2}{*}{$\operatorname{Inoc}^{x}$} & \multirow[b]{2}{*}{ Crop $^{y}$} & \multirow[b]{2}{*}{$\operatorname{Irg}^{\mathbf{z}}$} & \multicolumn{2}{|c|}{ Herbicide $^{t}$} \\
\hline & & Date & GS & & & & & Pre & Post \\
\hline \multicolumn{10}{|l|}{2013} \\
\hline Bo, 11 Jun & MS: AG3231 (4), MR: AG2931 (3) & 23 Sep & R6-R7 & $\ldots$ & Yes & Corn & No & S-met & Glyp \\
\hline Ur, 14 May & MS: NK38H8 (5), MR: NK39U2 (2) & 29 Aug & R6.2 & 10 Oct & Yes & Soy & Yes & Sulf + Clor & Glyp \\
\hline La, 15 May & MS: DSR3019 (2.5), MR: DSR3216 (1.8) & 13 Sep & R6-R7 & 26 Sep & Yes & Soy & Yes & Flum & Glyp and Flua + Feno \\
\hline De, 1 May & MS: P92Y60 (4), MR: P92Y51 (7) & 16 Aug & R6 & 3 Oct & No & Corn & Yes & Sulf + Metr and S-met & \\
\hline $\mathrm{Hg}, 8 \mathrm{Jun}$ & MS: P31-10RY (2), MR: P31-11RY (5) & $11 \mathrm{Sep}$ & R5 & 24 Oct & No & Soy & No & No & Glyp \\
\hline Rd, 8 Jun & MS: P31-10RY (2), MR: P31-11RY (5) & 10 Sep & R5 & $14 \mathrm{Nov}$ & No & Soy & No & No & Glyp \\
\hline \multicolumn{10}{|c|}{ (7) } \\
\hline Am, 6 May & MS: P92Y60 (4), MR: P92Y83 (7) & 8 Sep & R6-R7 & 6 Oct & Yes & Corn & Yes & Pend and Carf Sulf & Glyp \\
\hline Ur, 6 May & MS: P92Y60 (4), MR: P92Y83 (7) & 3 Sep & $\mathrm{R} 7$ & 21 Oct & Yes & Soy & Yes & Sulf + Clor & Glyp \\
\hline Wa, 3 Jun & MS: P92Y60 (4), MR: P92Y83 (7) & 28 Aug & R5.5 & $3 \mathrm{Nov}$ & Yes & Corn & Yes & $\mathrm{Chl}+\mathrm{Metr}$ & Glyp \\
\hline De, 6 May & MS: P92Y60 (4), MR: P92Y83 (7) & 26 Aug & R6-R7 & 1 Oct & No & Corn & Yes & Sulf + Metr and S-met & Quiz \\
\hline $\mathrm{Hg}, 28$ May & MS: P31-10RY (2), MR: P31-11RY (5) & 27 Aug & R5-R6 & 23 Oct & No & Wheat & No & No & Glyp \\
\hline Rd, 28 May & MS: P31-10RY (2), MR: P31-11RY (5) & $3 \mathrm{Sep}$ & R5-R6 & 30 Oct & No & Corn & No & No & Glyp \\
\hline
\end{tabular}

${ }^{\mathrm{r}}$ Abbreviations: Jun = June, Aug = August, Sep = September, Oct = October, Nov = November

${ }^{s}$ Sudden death syndrome (SDS). Growth stages (GS): R5 = beginning of seed formation, R6 = full seed, and R7 = beginning maturity.

${ }^{\mathrm{t}}$ S-met $=$ S-metachlor, Glyp = Glyphosate, Sulf = Sulfentrazone, Clor = Cloransulam-mehtyl, Flum = Flumioxazin, Flua $=$ Fluazifop-P-butyl, Feno = Fenoxaprop-p-ethyl, Metr = Metribuzin, Pend $=$ Pendimethalin, Carf $=$ Carfentrazone-ethyl, Chl $=$ Chlorimuron, and Quiz = Quizalofop-p-ethyl.

u Year, locations, and date of planting (DOP): Bo = Boone, IA; Ur = Urbana, IL; La = Lafayette, IN; De = Decatur, MI; Hg = Highgate, ON; Rd = Rodney, ON; $\mathrm{Am}=\mathrm{Ames}, \mathrm{IA} ;$ and $\mathrm{Wa}=$ Wanatah, $\mathrm{IN}$.

${ }^{\vee}$ Cultivar and SDS rating (in parentheses). MS = moderately susceptible to SDS and MR = moderately resistant to SDS. Pioneer (P) cultivars on a 1-to-9 scale, with 1 = susceptible; Asgrow (AG) and Northrup King (NK) cultivars on a 1-to-9 scale, with 1 = resistant; Dairyland seed (DSR) cultivars on a 1-to-5 scale, with $1=$ resistant

${ }^{\text {w}}$ Date of harvest. Yield data were not collected from Boone, IA in 2013 because experimental plots were bulk harvested by mistake.

x Inoculation. Plants were inoculated as follows: Iowa, the Fusarium virguliforme isolate NE 305 at $8.3 \mathrm{~g}$ of infested sorghum per linear meter of row; Illinois isolate Mont-1 at $4.1 \mathrm{~cm}^{3}$ of infested ground sorghum per linear meter of row; and Indiana, a mixture of three isolates collected locally (NRRL 22823, 00-11-183, and INS12-10 \#3-1) at $8.3 \mathrm{~g}$ of infested sorghum per linear meter of row.

y Previous crop: corn, soybean (soy), or wheat.

${ }^{\mathrm{z}}$ Irrigation. In Illinois, drip irrigation was set up starting June and ran every week for 6 weeks; approximately $2.5 \mathrm{~cm}$ of water was delivered each week. In the second year in Iowa, drip irrigation was set up in the first week of August and ran six times at 1-week intervals; approximately $2.5 \mathrm{~cm}$ of water was delivered each time. In Indiana, between the growth stages V5 and R5, approximately $2.5 \mathrm{~cm}$ of water was delivered in weeks when natural precipitation did not occur through overhead irrigation. In Michigan, up to $2.5 \mathrm{~cm} /$ week was applied through overhead pivot irrigation starting after emergence and through R5. 
Treatment effect size (the difference in mean for each treatment relative to the control mean, $\left.D=\bar{X}_{\text {treated }}-\bar{X}_{\text {control }}\right)$ and standard error of the difference were calculated postmodel fitting from metaanalysis estimates. The Lsmeans statement in PROC GLIMMIX was utilized to obtain the contrast estimates and the associated standard errors of the difference. Lower and upper limits of the 95\% confidence interval (CI95\%) of the mean difference were obtained from the equation $C 195 \%$ (effect) $=$ effect $\pm 1.96 \times S E_{\text {effect }}$. From the mean difference, mean percent difference relative to the control due to the fungicide treatment was estimated from the equation $(\bar{D} /$ control mean $\times 100$. For yield and SDS data, the meta-analysis model was further expanded to determine the influence of baseline disease level on treatment effect. Experiments were grouped into two categories based on the mean FDX in the control: level 1 (low) $=$ an FDX of less than 10 and level 2 (high) $=$ an FDX of more than 10. Each individual study was given a score of 1 or 2 based on mean FDX in control plots. The value of FDX $=10$ was chosen as a threshold to separate disease levels into low or high because foliar symptoms are clearly noticed in the field when it exceeds the level of 10 FDX. In addition, we have seen a greater effect of fluopyram seed treatment in our larger data set when disease level was more than the value of 10 FDX (Y. Kandel, unpublished data). The base disease level was used as a moderator variable and considered as a fixedeffect term in the meta-analysis.

Weather data collection. Monthly cumulative precipitation and soil temperature at planting for each experiment were obtained from the weather stations installed in the experimental plots or from a station located near the experimental sites through public weather service websites (http://w2.weather.gov/climate/ or http://mesonet.agron. iastate.edu/).

\section{Results}

Plant population. Plant population was influenced by fungicide treatments $(P<0.10)$ in 3 of the 12 experiments (Boone, IA in 2013; Decatur, MI; and Highgate, ON in 2014). Plots with fluopyram seed treatment had fewer plants than other treatments in Highgate, ON in 2014 (Table 3), which was 6\% less when compared with the control. Fungicide-cultivar interaction was not significant in any of the experiments at $P=0.10$.

Root rot and $F$. virguliforme DNA concentration. Root rot severity was estimated in 6 of the 12 experiments. Fungicide treatment significantly affected root rot severity in Ames, IA in $2014(P=0.09)$ but no differences were observed in the other experiments (Table 4). In Iowa, the fluopyram seed treatment reduced root rot by $24.6 \%$ compared with the control. Root rot severity was affected by cultivar in Boone, IA in $2013(P=0.10)$ and in Ames, IA $(P<0.01)$ and Wanatah, IN $(P=0.02)$ in 2014 but the trend was not consistent between the two cultivars. The moderately resistant (MR) cultivar had more root rot than moderately susceptible (MS) cultivars in Ames, IA but, in Boone, IA and Wanatah, IN, the SDS-susceptible cultivar had more root rot (Table 4).

$F$. virguliforme DNA in soybean roots was quantified in 10 experiments. Concentration of $F$. virguliforme DNA from base seed treatment plots ranged between 0.05 and $158.9 \mathrm{fg} / \mathrm{ng}$ of total DNA. There was no effect of fungicide treatment on concentration of $F$. virguliforme DNA in 9 of the 10 experiments (Table 5). F. virguliforme DNA concentration differed between the MS and MR cultivars in Ames, IA, Wanatah, IN, and Decatur, MI in 2014; however, the trend was not consistent. In Wanatah, IN, MS cultivar had more $F$. virguliforme DNA concentration than the MR cultivar but the other two sites had more $F$. virguliforme DNA in MR cultivars (Table 5).

Foliar SDS symptoms. Foliar SDS levels varied greatly in the control treatment across the experiments; FDX values ranged from no disease to over 30 (Table 6). Foliar SDS symptoms were first observed during and after flowering in most experiments where the disease was reported. In general, greater FDX values were noted in control plots during 2014 than 2013, reflecting that conditions were more favorable for SDS development in 2014 than in 2013. In 2013, no visible SDS symptoms were observed in Lafayette, IN and low disease levels were observed in most experiments. Other diseases

Table 2. Treatment combinations, rate, and time of applications in the field experiments carried out in four states in the United States and in Ontario, Canada in 2013 and $2014^{\mathrm{w}}$

\begin{tabular}{|c|c|c|c|c|c|c|c|c|c|c|c|c|c|c|}
\hline \multirow[b]{2}{*}{$\operatorname{Trt}^{\mathbf{x}}$} & \multirow[b]{2}{*}{$\mathbf{T}^{\mathbf{y}}$} & \multirow[b]{2}{*}{$\mathbf{R}^{\mathbf{z}}$} & \multicolumn{6}{|c|}{2013} & \multicolumn{6}{|c|}{2014} \\
\hline & & & Bo & Ur & La & De & $\mathbf{H g}$ & Rd & Am & Ur & Wa & De & Hg & Rd \\
\hline 1, Base & ST & $\ldots$ & 11 Jun & 14 May & 15 May & 1 May & 8 Jun & 8 Jun & 6 May & 6 May & 3 Jun & 6 May & 28 May & 28 May \\
\hline 2, Fluo & ST & 0.15 & 11 Jun & 14 May & 15 May & 1 May & 8 Jun & 8 Jun & 6 May & 6 May & 3 Jun & 6 May & 28 May & 28 May \\
\hline 3, Fluo & IF & 0.23 & 11 Jun & 14 May & 15 May & 1 May & 8 Jun & 8 Jun & 6 May & 6 May & 3 Jun & 6 May & 28 May & 28 May \\
\hline 4, Pyra & IF & 0.11 & 11 Jun & 14 May & 15 May & 1 May & 8 Jun & 8 Jun & 6 May & 6 May & 3 Jun & 6 May & 28 May & 28 May \\
\hline 5 , Fluo & V6 & 0.23 & $15 \mathrm{Jul}$ & $3 \mathrm{Jul}$ & $2 \mathrm{Jul}$ & 27 Jun & $12 \mathrm{Jul}(\mathrm{V} 4)$ & 12 Jul (V4) & $15 \mathrm{Jul}$ & 27 Jun & $18 \mathrm{Jul}$ & $\ldots$ & $16 \mathrm{Jul}$ & $21 \mathrm{Jul}$ \\
\hline 6, Pyra + Flux & V6 & 0.12 & $15 \mathrm{Jul}$ & $3 \mathrm{Jul}$ & $2 \mathrm{Jul}$ & 27 Jun & $12 \mathrm{Jul}$ (V4) & 12 Jul (V4) & $15 \mathrm{Jul}$ & 27 Jun & $18 \mathrm{Jul}$ & $\ldots$ & $16 \mathrm{Jul}$ & $21 \mathrm{Jul}$ \\
\hline 7, Fluo & $\mathrm{R} 1$ & 0.23 & $26 \mathrm{Jul}$ & $16 \mathrm{Jul}$ & $16 \mathrm{Jul}$ & 27 Jun & $23 \mathrm{Jul}$ & $23 \mathrm{Jul}$ & $\ldots$ & $\ldots$ & $\ldots$ & $\ldots$ & $\ldots$ & $\ldots$ \\
\hline 8, Pyra + Flux & $\mathrm{R} 1$ & 0.12 & $26 \mathrm{Jul}$ & $16 \mathrm{Jul}$ & $16 \mathrm{Jul}$ & 27 Jun & $23 \mathrm{Jul}$ & $23 \mathrm{Jul}$ & $\ldots$ & $\ldots$ & $\ldots$ & $\ldots$ & $\ldots$ & $\ldots$ \\
\hline 9, Fluo & R3 & 0.23 & 2 Aug & $23 \mathrm{Jul}$ & $23 \mathrm{Jul}$ & $11 \mathrm{Jul}$ & 8 Aug & 8 Aug & $\ldots$ & $\ldots$ & $\ldots$ & $\ldots$ & $\ldots$ & $\ldots$ \\
\hline $\begin{array}{l}\text { 10, Fluo and } \\
\text { Pyra + Flux }\end{array}$ & $\mathrm{R} 3$ & $0.23+0.12$ & $2 \mathrm{Aug}$ & $23 \mathrm{Jul}$ & $23 \mathrm{Jul}$ & $11 \mathrm{Jul}$ & 8 Aug & 8 Aug & $\ldots$ & $\cdots$ & $\ldots$ & $\ldots$ & $\ldots$ & $\ldots$ \\
\hline $\begin{array}{l}\text { 11, Fluo and } \\
\text { Prot + Trif }\end{array}$ & $\mathrm{R} 3$ & $0.23+0.21$ & 2 Aug & $23 \mathrm{Jul}$ & $23 \mathrm{Jul}$ & $11 \mathrm{Jul}$ & 8 Aug & 8 Aug & $\ldots$ & $\ldots$ & $\ldots$ & $\cdots$ & $\ldots$ & $\cdots$ \\
\hline 12, Pyra + Flux & $\mathrm{R} 3$ & 0.12 & $2 \mathrm{Aug}$ & $23 \mathrm{Jul}$ & $23 \mathrm{Jul}$ & $11 \mathrm{Jul}$ & 8 Aug & 8 Aug & $\ldots$ & $\ldots$ & $\ldots$ & $\ldots$ & $\ldots$ & $\ldots$ \\
\hline 13, Prot + Trif & R3 & 0.12 & 2 Aug & $23 \mathrm{Jul}$ & $23 \mathrm{Jul}$ & $11 \mathrm{Jul}$ & 8 Aug & 8 Aug & $\ldots$ & $\ldots$ & $\ldots$ & $\ldots$ & $\ldots$ & $\ldots$ \\
\hline 14, Pyra + Flux & IF & 0.12 & $\ldots$ & $\ldots$ & $\ldots$ & $\ldots$ & $\ldots$ & $\ldots$ & 6 May & 6 May & 3 Jun & 6 May & 28 May & 28 May \\
\hline 15 , Fluo & V3 & 0.23 & $\ldots$ & $\ldots$ & $\ldots$ & $\ldots$ & $\ldots$ & $\ldots$ & 25 Jun & 12 Jun & $2 \mathrm{Jul}$ & 12 Jun & $1 \mathrm{Jul}$ & $10 \mathrm{Jul}$ \\
\hline 16, Pyra + Flux & V3 & 0.12 & $\ldots$ & $\ldots$ & $\ldots$ & $\ldots$ & $\ldots$ & $\ldots$ & 25 Jun & 12 Jun & $2 \mathrm{Jul}$ & 12 Jun & $1 \mathrm{Jul}$ & $10 \mathrm{Jul}$ \\
\hline
\end{tabular}

${ }^{w}$ Locations: Bo = Boone Iowa; Ur = Urbana, IL; La = Lafayette, IN; De = Decatur, MI; Hg = Highgate, ON; Rd = Rodney, ON; Am = Ames, IA; and Wa = Wanatah, IN.

${ }^{x}$ Treatments: Base $($ control $)=$ base seed treatment by Bayer CropScience with prothioconazole $($ Prot $)+$ penflufen + metalaxyl $($ EverGol Energy, 0.019 mg a.i./seed; Bayer CropScience), metalaxyl (Allegiance, $0.02 \mathrm{mg}$ a.i./seed; Bayer CropScience), and clothianidin + Bacillus firmus (Poncho/VOTiVO, 0.13 mg a.i./seed; Bayer CropScience); fluopyram (Fluo) (ILeVO and Luna Privilege, Bayer CropScience; ILeVO was used in seed treatment and Luna Privilege was used for in-furrow and foliar applications); pyraclostrobin (Pyra) (Headline EC; BASF); pyraclostrobin + fluxapyroxad (Flux) (Priaxor; BASF); and prothioconazole + trifloxystrobin (Trif) (Stratego YLD; Bayer CropScience).

y Timing of fungicide application: ST = treated seed, IF = in-furrow application, V3 = foliar applications at V3 (three unrolled trifoliates), V6 = foliar applications at V6 (six unrolled trifoliates), R1 = foliar application at R1 (beginning of flowering), and R3 = foliar application at R3 (beginning of pod formation). Treatments 7 to 13 were not applied in 2014, and 14 to 16 were not applied in 2013. In 2013, treatments 5 and 6 were applied at V4 in Ontario.

${ }^{\mathrm{z}}$ Rate of application: seed treatment with fluopyram was applied at $0.15 \mathrm{mg}$ a.i./seed. Rate of in-furrow and foliar applications were active ingredient or active equivalent in kilograms per hectare. 
that are confused with SDS (in particular, brown stem rot caused by Cadophora gregata and northern stem canker caused by Diaporthe phaseolorum var. caulivora; Hartman et al. 2015b; Roy et al. 1997) were not prevalent in any of the experiments.

Fungicide treatment significantly affected $(P<0.10)$ FDX in Urbana, IL and Decatur, MI in 2013 and Urbana, IL, Wanatah, IN, and Rodney, ON in 2014 (Table 6). Mean comparison in these locations indicated that fluopyram applied as a seed treatment or infurrow application reduced SDS compared with other treatments. A 20 to 95\% reduction in FDX was observed with fluopyram seed treatment in these locations. All other in-furrow treatments had FDX values similar to the control treatment, except in Wanatah, IN in 2014, where pyraclostrobin + fluxapyroxad in-furrow applications had lower FDX. Foliar fungicide applications did not reduce FDX compared with the control in most of the experiments.

Cultivar effect on SDS severity was significant $(P<0.05)$ in Urbana, IL and Highgate, ON in 2013 and in Wanatah, IN, Ames, IA, and both Ontario locations in 2014 (Table 6). In experiments with a significant cultivar effect, the FDX of cultivars designated as MR to SDS ranged from 0.3 to 15.8 whereas the FDX of MS cultivars ranged from 2.1 to 55.1 (Table 6). The fungicide treatment-cultivar interaction was not significant in any experiments, except in Urbana, IL in $2013(P<0.01)$. Although the cultivar-treatment interaction was significant in Illinois, it did not change the treatment trend. For instance, the fluopyram seed treatment (FDX $=8.2$ in MS and 3.0 in MR) or in-furrow application (FDX $=3.7$ in $\mathrm{MS}$ and 0.1 in MR) had lower disease index than the control (FDX $=40.0$ in MS and 14.3 in MR) in both cultivars.

Grain yield. The effect of fungicide treatments on yield was significant $(P<0.10)$ for Urbana, IL and Highgate, ON in 2013 and Wanatah, IN in 2014. At these locations, fluopyram seed treatment increased yields by 6 to $11 \%$ compared with the control treatment (Table 7). An average yield response (difference in yield from the control) measured over three experiments with significant effect was $284 \mathrm{~kg} / \mathrm{ha}$ for the fluopyram seed treatment and $136 \mathrm{~kg} / \mathrm{ha}$ for the fluopyram in-furrow application. In-furrow applications of pyraclostrobin and pyraclostrobin + fluxapyroxad had similar yield compared with base seed treatment in all experiments (Table 7). Foliar application at R3 with fluopyram and pyraclostrobin + fluxapyroxad increased yield at Highgate, $\mathrm{ON}$ and resulted in $11.1 \%$ greater yield compared with the control. In Wanatah, IN during 2014, fluopyram applied at V3 produced $7.9 \%$ more yield when compared with the control (Table 7).

Yield differences between the MS and MR cultivars were statistically different for 6 of 11 experiments (Table 7). For all experiments where significant difference was observed, MR cultivars had significantly greater $(P<0.10)$ grain yield than MS cultivars, except in Lafayette, IN and Decatur, MI in 2013 (Table 7). In Rodney, ON in 2014, the main effects of fungicide and cultivar were not

Table 4. Main effects of fungicide treatments and cultivars for root rot severity measured at growth stage V2 to V3 for 6 field experiments performed in Illinois, Indiana, Iowa, and Michigan in the United States in 2013 and 2014 ${ }^{\mathrm{v}}$

\begin{tabular}{|c|c|c|c|c|c|c|c|c|}
\hline \multirow[b]{3}{*}{ Treatments $^{x}$} & \multirow[b]{3}{*}{ Time $^{y}$} & \multirow[b]{3}{*}{ Rate $^{\mathbf{z}}$} & \multicolumn{6}{|c|}{$\begin{array}{l}\text { Least square means root } \\
\text { rot severity }(\%)^{\mathrm{w}}\end{array}$} \\
\hline & & & \multicolumn{3}{|c|}{2013} & \multicolumn{3}{|c|}{2014} \\
\hline & & & Bo & $\mathbf{U r}$ & De & Am & Wa & De \\
\hline Base (control) & ST & $\ldots$ & 1.6 & 12.3 & 52.6 & $23.2 \mathrm{a}$ & 14.6 & 4.8 \\
\hline Fluo & ST & 0.15 & 1.8 & 9.0 & 46.6 & $17.5 \mathrm{~b}$ & 14.1 & 3.7 \\
\hline Fluo & IF & 0.23 & 2.4 & 15.3 & 51.3 & $21.9 \mathrm{a}$ & 15.5 & 3.5 \\
\hline Pyra & IF & 0.11 & 2.4 & 16.0 & 50.5 & $24.3 \mathrm{a}$ & 14.5 & 5.5 \\
\hline Pyra + Flux & IF & 0.12 & $\ldots$ & $\ldots$ & $\ldots$ & $20.0 \mathrm{ab}$ & 14.9 & 4.9 \\
\hline$P>F$ & $\ldots$ & $\ldots$ & 0.56 & 0.30 & 0.63 & 0.09 & 0.31 & 0.11 \\
\hline \multicolumn{9}{|l|}{ Cultivar } \\
\hline SDS-MS & $\ldots$ & $\ldots$ & 2.5 & 14.6 & 49.9 & 17.7 & 15.5 & 4.1 \\
\hline SDS-MR & $\ldots$ & $\ldots$ & 1.6 & 11.6 & 50.5 & 25.1 & 13.9 & 4.9 \\
\hline$P>F$ & $\ldots$ & $\ldots$ & 0.10 & 0.32 & 0.87 & $<0.01$ & 0.02 & 0.36 \\
\hline
\end{tabular}

${ }^{\mathrm{v}}$ Locations: $\mathrm{Bo}=$ Boone Iowa; Ur = Urbana, IL; De = Decatur, MI; Am = Ames, IA; and Wa = Wanatah, IN. Means were separated by Fisher's protected least significant difference. Means followed by the same letter within a column do not differ significantly at $P=0.10$.

${ }^{w}$ Root rot was estimated as percentage of root area covered with necrotic lesions.

$\mathrm{x}$ Treatments: Base $($ control $)=$ base seed treatment by Bayer CropScience with prothioconazole + penflufen + metalaxyl (EverGol Energy, $0.019 \mathrm{mg}$ a.i./seed; Bayer CropScience), metalaxyl (Allegiance, $0.02 \mathrm{mg}$ a.i./seed; Bayer CropScience), and clothianidin + Bacillus firmus (Poncho/VOTiVO, $0.13 \mathrm{mg}$ a.i./seed; Bayer CropScience); fluopyram (Fluo) (ILeVO and Luna Privilege, Bayer CropScience; ILeVO was used in seed treatment and Luna Privilege was used for in-furrow and foliar applications); pyraclostrobin (Pyra) (Headline EC; BASF); and pyraclostrobin + fluxapyroxad (Flux) (Priaxor; BASF). Cultivars: SDS-MS = moderately susceptible to sudden death syndrome (SDS) and SDS-MR = moderately resistant to SDS designated based on company ratings. Specific cultivars were different across locations and years

y Timing of fungicide application: ST $=$ treated seed and IF $=$ in-furrow application. In-furrow pyraclostrobin + fluxapyroxad was not tested in 2013.

${ }^{\mathrm{z}}$ Rate of application: seed treatment rate is in milligrams of active ingredient per seed. Rate of in-furrow and foliar applications are active ingredient or active equivalent in kilograms per hectare.

Table 3. Main effects of fungicide treatments and cultivars for plant population measured at growth stage V2 to V3 for 12 field experiments performed in Illinois, Indiana, Iowa, and Michigan in the United States and in Ontario, Canada in 2013 and 2014

\begin{tabular}{|c|c|c|c|c|c|c|c|c|c|c|c|c|c|c|}
\hline \multirow[b]{3}{*}{ Treatments ${ }^{x}$} & \multirow[b]{3}{*}{$\operatorname{Time}^{\mathbf{y}}$} & \multirow[b]{3}{*}{ Rate $^{\mathbf{z}}$} & \multicolumn{12}{|c|}{ Least square means plant population (number of plants/ha) ${ }^{\mathbf{w}}$} \\
\hline & & & \multicolumn{6}{|c|}{2013} & \multicolumn{6}{|c|}{2014} \\
\hline & & & Bo & $\mathbf{U r}$ & La & De & $\mathrm{Hg}$ & Rd & Am & $\mathbf{U} \mathbf{r}$ & Wa & De & $\mathbf{H g}$ & Rd \\
\hline Base & ST & $\ldots$ & $253,035 \mathrm{~b}$ & 312,558 & 243,160 & 296,469 & 490,527 & 505,750 & 285,660 & 333,001 & 334,346 & $321,089 \mathrm{a}$ & $454,312 \mathrm{a}$ & 439,563 \\
\hline Fluo & ST & 0.15 & $257,135 \mathrm{~b}$ & 316,324 & 239,395 & 246,340 & 476,072 & 500,368 & 290,502 & 323,587 & 330,849 & 316,631 a & $425,397 \mathrm{~b}$ & 440,729 \\
\hline Fluo & IF & 0.23 & $263,288 \mathrm{ab}$ & 318,476 & 234,239 & 262,639 & 476,841 & 492,218 & 275,439 & 335,960 & 357,659 & 314,019 a & $449,471 \mathrm{a}$ & 434,811 \\
\hline Pyra & IF & 0.11 & 286,664 a & 309,061 & 234,284 & 269,098 & 489,604 & 502,521 & 301,261 & 329,504 & 329,721 & 318,015 a & $456,599 \mathrm{a}$ & 435,214 \\
\hline Pyra + Flux & IF & 0.12 & $\ldots$ & $\ldots$ & $\ldots$ & $\ldots$ & $\ldots$ & $\ldots$ & 288,888 & 334,346 & 326,277 & $295,113 \mathrm{~b}$ & $452,026 \mathrm{a}$ & 434,273 \\
\hline$P>F$ & $\ldots$ & $\ldots$ & 0.10 & 0.61 & 0.61 & 0.19 & 0.20 & 0.55 & 0.67 & 0.58 & 0.13 & 0.05 & $<0.01$ & 0.92 \\
\hline \multicolumn{15}{|l|}{ Cultivars } \\
\hline SDS-MS & $\ldots$ & $\ldots$ & 267594 & 315,921 & 258,470 & 264,946 & 473,766 & 491,988 & 298,248 & 333,862 & 339,938 & 298371 & 438873 & 433,780 \\
\hline SDS-MR & $\ldots$ & $\ldots$ & 262467 & 312,289 & 217,069 & 272,327 & 492,756 & 508,441 & 278,451 & 328,697 & 331,602 & 327575 & 456249 & 440,056 \\
\hline$P>F$ & $\ldots$ & $\ldots$ & 0.62 & 0.68 & $<0.01$ & 0.66 & 0.20 & 0.22 & 0.12 & 0.35 & 0.39 & 0.05 & 0.01 & 0.31 \\
\hline
\end{tabular}

${ }^{\mathrm{w}}$ Locations: $\mathrm{Bo}=$ Boone Iowa; Ur = Urbana, IL; La = Lafayette, IN; De = Decatur, MI; Hg = Highgate, ON; Rd = Rodney, ON; Am = Ames, IA; and Wa = Wanatah, IN. Means were separated by Fisher's protected least significant difference. Means followed by the same letter within a column do not differ significantly at $P=0.10$.

x Treatments: Base $($ control $)=$ base seed treatment by Bayer CropScience with prothioconazole + penflufen + metalaxyl $($ EverGol Energy, 0.019 mg a.i./seed; Bayer CropScience), metalaxyl (Allegiance, $0.02 \mathrm{mg}$ a.i./seed; Bayer CropScience), and clothianidin + Bacillus firmus (Poncho/VOTiVO, 0.13 mg a.i./seed; Bayer CropScience); fluopyram (Fluo) (ILeVO and Luna Privilege, Bayer CropScience; ILeVO was used in seed treatment and Luna Privilege was used for in-furrow and foliar applications); pyraclostrobin (Pyra) (Headline EC; BASF); and pyraclostrobin + fluxapyroxad (Flux) (Priaxor; BASF). Cultivars: SDS-MS = moderately susceptible to sudden death syndrome (SDS) and SDS-MR = moderately resistant to SDS designated based on company ratings. Specific cultivars were different across locations and years

y Timing of fungicide application: ST $=$ treated seed and IF $=$ in-furrow application. In-furrow pyraclostrobin + fluxapyroxad was not tested in 2013.

${ }^{\mathrm{z}}$ Rate of application: seed treatment rate is in milligrams of active ingredient per seed. Rate of in-furrow and foliar applications are active ingredient or active equivalent in kilograms per hectare. 
significant but cultivar-fungicide interaction was significant $(P=$ 0.02 ). Separate analysis for each variety determined that yield difference among fungicide treatments was significant in the resistant cultivar (data not presented).

Correlations among SDS and other variables. FDX and yield were negatively correlated in all experiments except in Highgate, ON in 2013 (Table 8). The Pearson's correlation coefficients for FDX versus yield in 2013 and 2014 ( $n=68$ to 72) ranged from -0.21 to -0.84 and from -0.30 to -0.95 , respectively. Mixed results were observed for the FDX versus root rot correlation; no significant correlation was found for three of the six experiments. In the other three with a significant correlation, only one experiment had a positive correlation. A positive correlation between FDX and $F$. virguliforme DNA (in femtograms) was observed in three of nine experiments, while negative correlation was observed in one experiment and the remaining five experiments showed no correlation. The number of observations $(n)$ used to correlate with fungal DNA and root rot were 29 to 32 in 2013 and 36 to 40 in 2014. Root rot severity versus yield was significantly $(P=0.05)$ negatively $(r=-0.31)$ correlated in Decatur, MI in 2014.

Quantitative synthesis of fluopyram efficacy based on metaanalysis. A meta-analysis result was presented only for fluopyram seed treatment and in-furrow application because these treatments were repeated in both years and were efficacious at reducing SDS in the meta-analysis $(P<0.05)$. The efficacies were based on difference in mean for each treatment relative to the control. Meta-analysis for plant population showed that the overall difference between fluopyram seed treatment and the control was significantly different from zero, which was $2.2 \%$ less in seed treatment compared with the control, while in-furrow treatment had no effect on plant population. Similarly, overall effect for root rot was significant for seed treatment $(P=0.04)$ only. The reduction in root rot due to the seed treatment was $7.3 \%$ in relation to the control. For $F$. virguliforme DNA concentration, the $\bar{D}$ values were not significantly different from zero for any of the treatments.

In both treatments, the overall mean difference for FDX was negative and significantly different from zero $(P<0.01)$. The effect size $(\bar{D})$ for seed treatment and in-furrow application was -5.8 and -4.2 , respectively (Table 9). The corresponding mean control percentage was 41.1 and $29.8 \%$, respectively. The effect size for an individual study was different; some experiments had positive disease response, meaning the fungicide-treated plots had more disease (Fig. 1.). This occurred in $27.2 \%$ of the studies. $D$ ranged from -31.8 to 2.5 and -36.4 to 6.9 for seed treatment and in-furrow application, respectively. Mean FDX in control plots varied among the studies. We ran a meta-analysis using baseline disease (disease level in control plots) as a moderator variable to test the influence of baseline disease level on the efficacy of fluopyram. For both treatments, the mean difference was not different from zero $(P>0.01)$ when disease level was low $($ FDX $<10)$. Response was significantly different from zero when disease level was high (FDX > 10) (Table 10).

Mean soybean yield varied among the experiments. Overall, the response of treatment for yield was positive and significantly different from zero for both seed treatment and in-furrow application $(P<$ 0.05; Table 9). The response was 193.2 and $142.3 \mathrm{~kg} / \mathrm{ha}$ for seed treatment and in-furrow application, respectively. The corresponding yield increase was 5.5 and $4.1 \%$. The yield difference for individual experiments was different; some of the experiments had negative response, meaning treated plots had less yield compared with the control for both treatments. This occurred in $22.7 \%$ of the studies for seed treatment and $27.2 \%$ of the studies for in-furrow application. Disease level influenced yield response by fungicide treatment. When disease level was low, yield increase was not significantly different from zero $(P>0.10)$ whereas, under high disease levels, both treatments significantly increased yield $(P<0.01$; Table 10$)$. Additional information about treatment summaries and residual variance from each individual study for all parameters (plant population, root rot, $F$. virguliforme DNA concentration, FDX, and yield) are available as Supplementary Tables S1 and S2).

Weather conditions. Precipitation patterns differed between 2013 and 2014 (Supplementary Table S3). For example, in Iowa in 2013, the months of June through September were drier compared with the 30 -year average and precipitation over the season (May to September) was about $20 \mathrm{~cm}$ less than the 30 -year average and nearly $38 \mathrm{~cm}$ less than 2014. In 2014, the precipitation over the season was about $19 \mathrm{~cm}$ higher than the 30-year average. A similar trend of dry conditions in 2013 and excessively wet conditions in 2014 was observed in Illinois and Indiana for the months of June through September. In Indiana, the cumulative precipitation for the season was $90 \mathrm{~cm}$, which was $44 \mathrm{~cm}$ higher than the 30-year average and

Table 5. Main effects of fungicide treatments and cultivars for Fusarium virguliforme DNA concentration measured at growth stage V2 to V3 for 10 field experiments performed in Illinois, Indiana, Iowa, and Michigan in the United States and in Ontario, Canada in 2013 and 2014v

Least square means $F$. virguliforme DNA concentration $(\mathrm{fg} / \mathrm{ng} \text { of total DNA })^{\mathrm{w}}$

\begin{tabular}{|c|c|c|c|c|c|c|c|c|c|c|c|c|}
\hline \multirow{2}{*}{ Treatments $^{\mathrm{x}}$} & \multirow[b]{2}{*}{ Time $^{\mathbf{y}}$} & \multirow[b]{2}{*}{ Rate $^{\mathrm{z}}$} & \multicolumn{5}{|c|}{2013} & \multicolumn{5}{|c|}{2014} \\
\hline & & & Bo & $\mathbf{U r}$ & La & $\mathrm{Hg}$ & Rd & Am & Wa & De & $\mathrm{Hg}$ & Rd \\
\hline Base & ST & $\ldots$ & 5.7 & 18.2 & 20.7 & 0.8 & 1.0 & 158.9 & 5.8 & 43.1 & 1.5 & $0.0 \mathrm{~b}$ \\
\hline Fluo & ST & 0.15 & 8.5 & 14.4 & 56.6 & 0.2 & 0.1 & 119.4 & 4.7 & 46.8 & 0.5 & $0.3 \mathrm{~b}$ \\
\hline Fluo & IF & 0.23 & 16.7 & 15.9 & 24.1 & 1.1 & 0.2 & 177.6 & 7.9 & 23.3 & 2.0 & $1.1 \mathrm{a}$ \\
\hline Pyra & IF & 0.11 & 8.1 & 22.4 & 89.1 & 0.5 & 0.2 & 183.1 & 8.1 & 35.3 & 2.7 & $0.2 \mathrm{~b}$ \\
\hline Pyra + Flux & IF & 0.12 & $\ldots$ & $\ldots$ & $\ldots$ & $\ldots$ & $\ldots$ & 270.9 & 9.4 & 49.8 & 3.4 & $0.1 \mathrm{~b}$ \\
\hline$P>F$ & $\ldots$ & $\ldots$ & 0.58 & 0.79 & 0.34 & 0.37 & 0.38 & 0.79 & 0.51 & 0.26 & 0.24 & 0.10 \\
\hline Cultivar & & & & & & & & & & & & \\
\hline SDS-MS & $\ldots$ & $\ldots$ & 11.2 & 23.9 & 60.7 & 0.5 & 0.4 & 108.5 & 10.0 & 17.6 & 2.1 & 0.3 \\
\hline SDS-MR & $\ldots$ & $\ldots$ & 10.0 & 11.6 & 34.6 & 0.8 & 0.3 & 255.5 & 4.3 & 61.7 & 2.0 & 0.4 \\
\hline$P>F$ & $\ldots$ & $\ldots$ & 0.70 & 0.34 & 0.40 & 0.44 & 0.74 & 0.09 & 0.03 & 0.03 & 0.89 & 0.68 \\
\hline
\end{tabular}

v Concentration of $F$. virguliforme DNA in total soybean root DNA was estimated using a $F$. virguliforme-specific quantitative polymerase chain reaction assay.

${ }^{\mathrm{w}}$ Locations: $\mathrm{Bo}=$ Boone Iowa; Ur = Urbana, IL; La = Lafayette, IN; Hg = Highgate, ON; Rd = Rodney, ON; Am = Ames, IA; Wa = Wanatah, IN; and De = Decatur, MI. Means were separated by Fisher's protected least significant difference. Means followed by the same letter within a column do not differ significantly at $P=0.10$.

${ }^{x}$ Treatments: Base $($ control $)=$ base seed treatment by Bayer CropScience with prothioconazole + penflufen + metalaxyl (EverGol Energy, 0.019 mg a.i./seed; Bayer CropScience), metalaxyl (Allegiance, $0.02 \mathrm{mg}$ a.i./seed; Bayer CropScience), and clothianidin + Bacillus firmus (Poncho/VOTiVO, 0.13 mg a.i./seed; Bayer CropScience); fluopyram (Fluo) (ILeVO and Luna Privilege, Bayer CropScience; ILeVO was used in seed treatment and Luna Privilege was used for in-furrow and foliar applications); pyraclostrobin (Pyra) (Headline EC; BASF); and pyraclostrobin + fluxapyroxad (Flux) (Priaxor; BASF). Cultivars: SDS-MS = moderately susceptible to sudden death syndrome (SDS) and SDS-MR = moderately resistant to SDS designated based on company ratings. Specific cultivars were different across locations and years

y Timing of fungicide application: ST = treated seed and IF = in-furrow application. In-furrow pyraclostrobin + fluxapyroxad was not tested in 2013.

${ }^{\mathrm{z}}$ Rate of application: seed treatment rate is in milligrams of active ingredient per seed. Rate of in-furrow and foliar applications are active ingredient or active equivalent in kilograms per hectare. 
$50 \mathrm{~cm}$ higher than 2013. Over the season, other locations also received more precipitation in 2014 than 2013, except in Michigan, which had supplemental irrigation. In Ontario, the month of July was especially wetter in 2014 than 2013 at both research locations.

\section{Discussion}

Our results show that fluopyram applied as a seed treatment or infurrow application reduced FDX compared with other fungicide treatments, including the base seed treatment in 5 of 12 experiments. The overall reduction in FDX based on meta-analysis was 41.1 and $29.8 \%$ by seed treatment and in-furrow application, respectively. Although the effect of fluopyram on other host systems has been documented (Fought et al. 2011; Labourdette et al. 2010; Meredith 2012; Proffer et al. 2013), this is the first report of its efficacy against SDS across a wide range of field and management regimes, and it provides new options for SDS management in the United States and Canada.

This is also the first research to report efficacy of a seed or infurrow product against SDS. Previous research has demonstrated that commercially available fungicides used in seed treatments are not effective against $F$. virguliforme (Weems et al. 2015). The complete mechanism behind how fluopyram reduces the symptoms associated with SDS is still not clearly understood. Carbon-14 radiolabeled studies have demonstrated the systemic movement of radiolabeled product into the tap root; however, product activity of translocated product has not been tested (J. Riggs, personal communication). Other fungicides that are currently available as a seed treatment or promoted for in-furrow applications have limited movement in the plant or move acropetally in the plant (Mueller et al. 2013). The limited fungicide mobility of many currently labeled fungicide active ingredients could explain why foliar applications and in-furrow applications of products other than fluopyram were not able to reduce SDS compared with the control treatment.

Fluopyram did not consistently reduce SDS when applied postemergence. Fluopyram moves acropetally in the plant and is not expected to move downward from foliage to root tissue, where infection occurred. This result supports general observations that the foliar fungicide applications do not affect SDS and verifies that application method is equally important for the management of SDS as the product applied.

Although, in general, fluopyram reduced SDS, there were some inconsistencies in its efficacy against SDS. Some of these inconsistencies can be explained by a difference in disease level across the locations and years. Soybean SDS disease levels were greater in 2014 than 2013, as reflected by the mean FDX values of control plots. This suggests that the growing conditions were more favorable for SDS development in the second year of the research. The most pronounced environmental difference between 2013 and 2014 was greater recorded precipitation in 2014 between June and the end of the season, although additional factors may have influenced SDS severity. Several other field studies have reported that high rainfall around soybean flowering and early reproductive stages is critical for SDS development (Hartman et al. 2015b; Leandro et al. 2013;

Table 6. Main effects of fungicide treatments and cultivars for foliar disease index (FDX) of sudden death syndrome measured in 12 field experiments carried out in Illinois, Indiana, Iowa, and Michigan in the United States and in Ontario, Canada in 2013 and 2014

\begin{tabular}{|c|c|c|c|c|c|c|c|c|c|c|c|c|c|c|}
\hline \multirow[b]{3}{*}{$\operatorname{Trt}^{\mathrm{x}}$} & \multirow[b]{3}{*}{$\mathbf{T}^{\mathbf{y}}$} & \multirow[b]{3}{*}{$\mathbf{R}^{\mathbf{z}}$} & \multicolumn{12}{|c|}{ Least square means FDXw } \\
\hline & & & \multicolumn{6}{|c|}{2013} & \multicolumn{6}{|c|}{2014} \\
\hline & & & Bo & Ur & La & De & Hg & Rd & Am & Ur & Wa & De & $\mathbf{H g}$ & Rd \\
\hline Base & ST & $\ldots$ & 1.0 & $27.2 \mathrm{a}-\mathrm{c}$ & 0.0 & $12.0 \mathrm{bc}$ & 9.4 & 4.0 & 19.1 & $15.4 \mathrm{a}$ & $1.9 \mathrm{ab}$ & 10.7 & 30.6 & $30.4 \mathrm{ab}$ \\
\hline Fluo & ST & 0.15 & 2.3 & $5.6 \mathrm{e}$ & 0.0 & $9.6 \mathrm{bc}$ & 4.0 & 0.3 & 8.3 & $5.0 \mathrm{c}$ & $0.1 \mathrm{e}$ & 12.5 & 28.5 & $14.7 \mathrm{c}$ \\
\hline Fluo & IF & 0.23 & 2.0 & $1.9 \mathrm{e}$ & 0.0 & $8.9 \mathrm{bc}$ & 1.0 & 8.0 & 6.3 & $9.7 \mathrm{bc}$ & $0.7 \mathrm{~b}-\mathrm{e}$ & 11.3 & 31.7 & $28.5 \mathrm{ab}$ \\
\hline Pyra & IF & 0.11 & 1.5 & $28.3 \mathrm{ab}$ & 0.0 & $8.9 \mathrm{bc}$ & 1.5 & 1.0 & 18.6 & $14.2 \mathrm{ab}$ & $1.5 \mathrm{a}-\mathrm{d}$ & 10.1 & 28.3 & $29.9 \mathrm{ab}$ \\
\hline Fluo & V6 & 0.23 & 1.2 & $21.6 \mathrm{a}-\mathrm{d}$ & 0.0 & $11.1 \mathrm{bc}$ & 0.8 & 6.5 & 14.2 & $13.1 \mathrm{ab}$ & $2.3 \mathrm{a}$ & $\ldots$ & 29.9 & $23.1 \mathrm{bc}$ \\
\hline Pyra + Flux & V6 & 0.12 & 2.6 & $18.8 \mathrm{~cd}$ & 0.0 & $7.1 \mathrm{c}$ & 5.5 & 3.8 & 18.1 & $10.7 \mathrm{ab}$ & $1.6 \mathrm{a}-\mathrm{c}$ & $\ldots$ & 32.2 & $28.8 \mathrm{ab}$ \\
\hline Fluo & $\mathrm{R} 1$ & 0.23 & 1.1 & $20.6 b-d$ & 0.0 & $9.9 \mathrm{bc}$ & 0.8 & 0.8 & $\ldots$ & $\ldots$ & $\ldots$ & $\ldots$ & $\ldots$ & $\ldots$ \\
\hline Pyra + Flux & R1 & 0.12 & 1.7 & $29.5 \mathrm{a}$ & 0.0 & $13.7 \mathrm{bc}$ & 1.8 & 0.4 & $\ldots$ & $\ldots$ & $\ldots$ & $\ldots$ & $\ldots$ & $\ldots$ \\
\hline Fluo & R3 & 0.23 & 1.8 & $20.1 \mathrm{~b}-\mathrm{d}$ & 0.0 & $8.8 \mathrm{bc}$ & 5.7 & 3.6 & $\ldots$ & $\ldots$ & $\ldots$ & $\ldots$ & $\ldots$ & $\ldots$ \\
\hline Fluo and Pyra + Flux & R3 & $0.23+0.12$ & 1.1 & $15.3 \mathrm{~d}$ & 0.0 & $11.6 \mathrm{bc}$ & 1.7 & 3.5 & $\ldots$ & $\ldots$ & $\ldots$ & $\ldots$ & $\ldots$ & $\ldots$ \\
\hline Fluo and Prot + Trif & R3 & $0.23+0.21$ & 1.5 & $19.8 \mathrm{~cd}$ & 0.0 & $22.8 \mathrm{a}$ & 0.6 & 7.5 & $\ldots$ & $\ldots$ & $\ldots$ & $\ldots$ & $\ldots$ & $\ldots$ \\
\hline Pyra + Flux & R3 & 0.12 & 1.7 & $17.9 \mathrm{~d}$ & 0.0 & $12.4 \mathrm{bc}$ & 2.3 & 1.2 & $\ldots$ & $\ldots$ & $\ldots$ & $\ldots$ & $\ldots$ & $\ldots$ \\
\hline Prot + Trif & R3 & 0.12 & 1.2 & $22.8 \mathrm{a}-\mathrm{d}$ & 0.0 & $14.4 \mathrm{~b}$ & 4.2 & 4.0 & $\ldots$ & $\ldots$ & $\ldots$ & $\ldots$ & $\ldots$ & $\ldots$ \\
\hline Pyra + Flux & IF & 0.12 & $\ldots$ & $\ldots$ & $\ldots$ & $\ldots$ & $\ldots$ & $\ldots$ & 21.5 & $13.1 \mathrm{ab}$ & $0.4 \mathrm{de}$ & 9.2 & 27.6 & $26.6 \mathrm{ab}$ \\
\hline Fluo & V3 & 0.23 & $\ldots$ & $\ldots$ & $\ldots$ & $\ldots$ & $\ldots$ & $\ldots$ & 12.2 & $10.6 \mathrm{ab}$ & $0.6 \mathrm{c}-\mathrm{e}$ & 12.1 & 23.6 & $35.7 \mathrm{a}$ \\
\hline Pyra + Flux & V3 & 0.12 & $\ldots$ & $\ldots$ & $\ldots$ & $\ldots$ & $\ldots$ & $\ldots$ & 13.6 & $10.2 \mathrm{~b}$ & $1.6 \mathrm{a}-\mathrm{c}$ & 12.5 & 33.2 & $27.1 \mathrm{ab}$ \\
\hline$P>F$ & $\ldots$ & $\ldots$ & 0.57 & $<0.01$ & NT & 0.06 & 0.18 & 0.50 & 0.35 & 0.06 & 0.02 & 0.98 & 0.81 & 0.06 \\
\hline \multicolumn{15}{|l|}{ Cultivar } \\
\hline SDS-MS & $\ldots$ & $\ldots$ & 0.9 & 30.7 & 0.0 & 12.0 & 5.1 & 4.4 & 25.8 & 13.1 & 2.1 & 13.1 & 55.1 & 38.6 \\
\hline SDS-MR & $\ldots$ & $\ldots$ & 2.3 & 7.6 & 0.0 & 11.2 & 0.9 & 2.5 & 3.5 & 9.5 & 0.3 & 9.3 & 3.9 & 15.8 \\
\hline$P>F$ & $\ldots$ & $\ldots$ & 0.14 & $<0.01$ & NT & 0.82 & 0.02 & 0.61 & 0.02 & 0.15 & 0.01 & 0.27 & $<0.01$ & $<0.01$ \\
\hline
\end{tabular}

${ }^{v}$ FDX of SDS was calculated using the formula FDX $=$ FDI $\times$ FDS/9. Disease incidence (FDI) was estimated as percentage of symptomatic plants per plot and foliar SDS severity (FDS) was scored on a 0 -to- 9 scale $(0=$ no disease and $9=$ premature death $)$ based on percentage of the chlorotic and necrotic leaf area and defoliation.

${ }^{\mathrm{w}}$ Locations: $\mathrm{Bo}=$ Boone Iowa; Ur = Urbana, IL; La = Lafayette, IN; De = Decatur, MI; Hg = Highgate, ON; Rd = Rodney, ON; Am = Ames, IA; and Wa = Wanatah, IN. Means were separated by Fisher's protected least significant difference. Means followed by the same letter within a column do not differ significantly at $P=0.10$.

x Treatments: Base $($ control $)=$ base seed treatment by Bayer CropScience with prothioconazole + penflufen + metalaxyl $($ EverGol Energy, 0.019 mg a.i./seed; Bayer CropScience), metalaxyl (Allegiance, $0.02 \mathrm{mg}$ a.i./seed; Bayer CropScience), and clothianidin + Bacillus firmus (Poncho/VOTiVO, 0.13 mg a.i./seed; Bayer CropScience); fluopyram (Fluo) (ILeVO and Luna Privilege, Bayer CropScience; ILeVO was used in seed treatment and Luna Privilege was used for in-furrow and foliar applications); pyraclostrobin (Pyra) (Headline EC; BASF); pyraclostrobin + fluxapyroxad (Flux) (Priaxor; BASF); and prothioconazole (Prot) + trifloxystrobin (Trif) (Stratego YLD; Bayer CropScience). Cultivars: SDS-MS = moderately susceptible to sudden death syndrome (SDS) and SDS-MR = moderately resistant to SDS designated based on company ratings. Specific cultivars were different across locations and years.

y Timing of fungicide application: ST = treated seed, IF = in-furrow application, V3 = foliar applications at V3 (three unrolled trifoliates), V6 = foliar applications at V6 (six unrolled trifoliates), R1 = foliar application at R1 (beginning of flowering), and R3 = foliar application at R3 (beginning of pod formation). Treatments 7 to 13 were not applied in 2014, and 14 to 16 were not applied in 2013. In 2013, treatments 5 and 6 were applied at V4 in Ontario. .

z Rate of application: seed treatment with fluopyram was applied at $0.15 \mathrm{mg}$ a.i./seed. Rate of in-furrow and foliar applications were active ingredient or active equivalent in kilograms per hectare. 
Roy et al. 1997; Scherm and Yang 1999; Scherm et al. 1998). Metaanalysis showed that the treatment effect on SDS was not significant when FDX values were below 10. In 2013, the only experiments where treatment had a significant effect were those with FDX values exceeding 12 in the control treatments. Conditions for SDS were more prevalent in 2014 and, although more locations had a significant treatment effect, there were three locations in 2014 where SDS levels were high but treatment did not significantly affect FDX and fluopyram did not consistently reduce FDX compared with the control. This inconsistency is common and can be influenced by several factors but reinforces the concept that SDS is difficult to manage and that farmers should consider more than one management practice to prevent yield loss due to disease.

Planting cultivars with some level of resistance has long been a standard recommendation for SDS management. Our research demonstrates that cultivar affects foliar SDS symptom development. Although we did not observe differences in symptom type between susceptible and resistant cultivars, as previously reported by Stephens et al. (1993b), we did observe that cultivars rated with better resistance to SDS had less disease than cultivars rated as more susceptible to SDS. This supports previous findings that host resistance plays an important role for SDS management and also confirms that cultivar is the first choice for SDS management (Mueller et al. 2003; Roy et al. 1997; Weems et al. 2015). However, because MR cultivars had disease levels similar to MS cultivars in some experiments, inoculum concentration and other soil and environment factors may also affect cultivar response to disease development.
Grain yield was negatively correlated with foliar SDS in all experiments, which was expected and consistent with several previous studies (Njiti et al. 1998; Rupe et al. 1993, 1997). Fungicide treatments significantly affected yield in three experiments. Within these locations, fluopyram increased yield in both seed treatment and infurrow application by up to $11 \%$. However, yield was not affected by fungicide treatment in the majority of site years. Meta-analysis showed that overall response for fluopyram seed treatment and infurrow application relative to the control was positive, although some experiments had a negative response. The inconsistent yield response might be due, in part, to the different level of disease present across the experiments. Effect size was greater for the higher disease category than lower disease category and only significantly different from zero when disease level was high. Several studies have reported that SDS may not affect yield, especially when symptoms appeared late in the growing season (Hershman et al. 1990; Stephens et al. 1993a; Wrather et al. 1995). In all experiments, soybean was planted in May or June, and research has reported that SDS is more severe when soybean crops are planted early in the season (Hershman et al. 1990), which is April in the north-central United States. Although researchers in this study targeted early planting dates, spring rainfall delayed planting in some locations. This may explain why, in some instances, fluopyram seed treatment significantly reduced FDX but did not affect yield. Interestingly, at one location, yield response of fluopyram seed treatment was observed even though the FDX was less than 5. This could be due to fluopyram's ability to control other root pathogens, which were not evaluated in this study, or as a result

Table 7. Main effects of fungicide treatments and cultivars for soybean yield measured in 11 field experiments carried out in Illinois, Indiana, Iowa, and Michigan in the United States and in Ontario, Canada in 2013 and 2014

\begin{tabular}{|c|c|c|c|c|c|c|c|c|c|c|c|c|c|}
\hline \multirow[b]{3}{*}{$\operatorname{Trt}^{\mathrm{x}}$} & \multirow[b]{3}{*}{$\mathbf{T}^{\mathbf{y}}$} & \multirow[b]{3}{*}{$\mathbf{R}^{\mathbf{z}}$} & \multicolumn{11}{|c|}{ Yield $(\mathrm{kg} / \mathrm{ha})^{\mathrm{w}}$} \\
\hline & & & \multicolumn{5}{|c|}{2013} & \multicolumn{6}{|c|}{2014} \\
\hline & & & $\mathbf{U r}$ & La & De & Hg & Rd & Am & $\mathbf{U r}$ & Wa & De & Hg & Rd \\
\hline Base & ST & . & 4,002 b-d & 4,047 & 2,587 & 4,015 b-f & 3,886 & 4,094 & 4,219 & $3,474 \mathrm{~cd}$ & 2,990 & 2,823 & 2,125 \\
\hline Fluo & ST & 0.15 & $4,248 \mathrm{ab}$ & 3,997 & 2,855 & $4,243 \mathrm{a}-\mathrm{d}$ & 3,684 & 4,199 & 4,394 & $3,852 \mathrm{a}$ & 3,071 & 3,065 & 2,726 \\
\hline Fluo & IF & 0.23 & 4,466 a & 4,114 & 3,053 & $3,796 \mathrm{fg}$ & 3,421 & 4,220 & 4,387 & $3,638 \mathrm{a}-\mathrm{c}$ & 3,129 & 3,105 & 2,437 \\
\hline Pyra & IF & 0.11 & $3,841 \mathrm{~d}$ & 4,070 & 2,597 & $4,356 a b$ & 3,610 & 4,130 & 4,343 & $3,275 \mathrm{~d}$ & 2,916 & 3,126 & 2,480 \\
\hline Fluo & V6 & 0.23 & $3,963 \mathrm{~cd}$ & 4,097 & 2,792 & $3,873 \mathrm{~d}-\mathrm{g}$ & 3,666 & 4,071 & 4,240 & $3,584 \mathrm{bc}$ & $\ldots$ & 3,109 & 2,698 \\
\hline Pyra + Flux & V6 & 0.12 & $4,195 \mathrm{bc}$ & 4,150 & 3,034 & $3,702 \mathrm{~g}$ & 3,678 & 4,046 & 4,319 & $3,534 \mathrm{bc}$ & $\ldots$ & 3,033 & 2,409 \\
\hline Fluo & $\mathrm{R} 1$ & 0.23 & 4,068 b-d & 4,021 & 2,840 & $3,865 \mathrm{e}-\mathrm{g}$ & 3,966 & $\ldots$ & $\ldots$ & $\ldots$ & $\ldots$ & $\ldots$ & $\ldots$ \\
\hline Pyra + Flux & $\mathrm{R} 1$ & 0.12 & $4,115 \mathrm{bc}$ & 4,143 & 2,768 & $3,922 \mathrm{c}-\mathrm{g}$ & 3,790 & $\ldots$ & $\ldots$ & $\ldots$ & $\ldots$ & $\ldots$ & $\ldots$ \\
\hline Fluo & R3 & 0.23 & $4,091 \mathrm{~b}-\mathrm{d}$ & 4,127 & 2,901 & 4,199 a-e & 4,001 & $\ldots$ & $\ldots$ & $\ldots$ & $\ldots$ & $\ldots$ & $\ldots$ \\
\hline $\begin{array}{l}\text { Fluo and } \\
\text { Pyra + Flux }\end{array}$ & $\mathrm{R} 3$ & $0.23+0.12$ & $4,242 a b$ & 4,066 & 2,967 & $4,460 \mathrm{a}$ & 3,954 & $\ldots$ & $\ldots$ & $\cdots$ & $\ldots$ & $\ldots$ & $\ldots$ \\
\hline $\begin{array}{l}\text { Fluo and } \\
\text { Prot + Trif }\end{array}$ & $\mathrm{R} 3$ & $0.23+0.21$ & $4,244 \mathrm{ab}$ & 4,275 & 2,912 & 4,284 a-c & 3,290 & $\cdots$ & $\ldots$ & $\cdots$ & $\ldots$ & $\ldots$ & $\cdots$ \\
\hline Pyra + Flux & R3 & 0.12 & $3,980 \mathrm{~cd}$ & 4,115 & 2,678 & 4,179 a-e & 3,904 & $\ldots$ & $\ldots$ & $\ldots$ & $\ldots$ & $\ldots$ & $\ldots$ \\
\hline Prot + Trif & R3 & 0.12 & $4,063 \mathrm{~b}-\mathrm{d}$ & 4,076 & 2,877 & $4,111 \mathrm{a}-\mathrm{f}$ & 3,599 & $\ldots$ & $\ldots$ & $\ldots$ & $\ldots$ & $\ldots$ & $\ldots$ \\
\hline Pyra + Flux & $\mathrm{IF}$ & 0.12 & $\ldots$ & $\ldots$ & $\ldots$ & $\ldots$ & $\ldots$ & 4,467 & 4,232 & $3,455 \mathrm{~cd}$ & 3,070 & 3,266 & 2,420 \\
\hline Fluo & V3 & 0.23 & $\ldots$ & $\ldots$ & $\ldots$ & $\ldots$ & $\ldots$ & 4,184 & 4,406 & $3,750 \mathrm{ab}$ & 3,422 & 3,526 & 2,315 \\
\hline Pyra + Flux & V3 & 0.12 & $\ldots$ & $\ldots$ & $\ldots$ & $\ldots$ & $\ldots$ & 3,998 & 4,331 & $3,486 \mathrm{~cd}$ & 3,005 & 3,217 & 2,369 \\
\hline$P>F$ & $\ldots$ & $\ldots$ & 0.02 & 0.61 & 0.58 & 0.02 & 0.32 & 0.71 & 0.50 & 0.01 & 0.30 & 0.46 & 0.52 \\
\hline \multicolumn{14}{|l|}{ Cultivar } \\
\hline SDS-MS & $\ldots$ & $\ldots$ & 3,532 & 4,262 & 3,119 & 4,018 & 3,325 & 4,114 & 4,274 & 3,485 & 3,114 & 2,106 & 1,899 \\
\hline SDS-MR & $\ldots$ & $\ldots$ & 4,702 & 3,938 & 2,552 & 4,137 & 4,129 & 4,200 & 4,364 & 3,637 & 3,058 & 4,176 & 2,985 \\
\hline$P>F$ & $\ldots$ & $\ldots$ & $<0.01$ & 0.07 & 0.09 & 0.52 & $<0.01$ & 0.68 & 0.38 & 0.27 & 0.79 & $<0.01$ & $<0.01$ \\
\hline
\end{tabular}

${ }^{\mathrm{w}}$ Locations: Ur = Urbana, IL; La = Lafayette, IN; De = Decatur, MI; Hg = Highgate, ON; Rd = Rodney, ON; Am = Ames, IA; and Wa = Wanatah, IN. Yield was not recorded in Boone, IA in 2013 because experimental plots were harvested in bulk by mistake. Means were separated by Fisher's protected least significant difference. Means followed by the same letter within a column do not differ significantly at $P=0.10$.

${ }^{x}$ Treatments: Base $($ control) $=$ base seed treatment by Bayer CropScience with prothioconazole + penflufen + metalaxyl (EverGol Energy, 0.019 mg a.i./seed; Bayer CropScience), metalaxyl (Allegiance, $0.02 \mathrm{mg}$ a.i./seed; Bayer CropScience), and clothianidin + Bacillus firmus (Poncho/VOTiVO, $0.13 \mathrm{mg}$ a.i./seed; Bayer CropScience); fluopyram (Fluo) (ILeVO and Luna Privilege, Bayer CropScience; ILeVO was used in seed treatment and Luna Privilege was used for in-furrow and foliar applications); pyraclostrobin (Pyra) (Headline EC; BASF); pyraclostrobin + fluxapyroxad (Flux) (Priaxor; BASF); and prothioconazole (Prot) + trifloxystrobin (Trif) (Stratego YLD; Bayer CropScience).

y Timing of fungicide application: ST = treated seed, IF = in-furrow application, V3 = foliar applications at V3 (three unrolled trifoliates), V6 = foliar applications at V6 (six unrolled trifoliates), R1 = foliar application at R1 (beginning of flowering), and R3 = foliar application at R3 (beginning of pod formation). Treatments 7 to 13 were not applied in 2014, and 14 to 16 were not applied in 2013. In 2013, treatments 5 and 6 were applied at V4 in Ontario.

${ }^{\mathrm{z}}$ Rate of application: seed treatment with fluopyram was applied at $0.15 \mathrm{mg}$ a.i./seed. Rate of in-furrow and foliar applications were active ingredient or active equivalent in kilograms per hectare. 
of nonfungicidal physiological benefits that occur due to fungicide application. Foliar applications of fluopyram at V3 and premix of pyraclostrobin + fluxapyroxad at R3 also increased yield in two sites, although SDS was not reduced. In addition to controlling visible disease symptoms, several nonfungicidal benefits of fungicide applications have also been documented previously (Smith et al. 2013)

Fungicide treatments did not consistently reduce root rot severity and concentration of $F$. virguliforme DNA in root tissue, despite varying levels of SDS. This could be, in part, because of low concentrations of $F$. virguliforme DNA or root rot present in seedlings. Likewise, cultivar had an inconsistent effect on root rot severity. Because root rot severity was mostly similar between the MR and MS cultivars, we might infer that the resistant cultivars chosen in this study may not have genes for resistance to root rot at the seedling stages. Other soilborne pathogens could be responsible for some of the root damage observed; however, these pathogens were not evaluated in this study. For the most part, there was no consistent correlation among root rot, F. virguliforme DNA concentration, and
FDX. This implies that root rot severity or fungal population at the seedling stage may not correlate with SDS symptoms during reproductive stages. This result was consistent with previous findings (Scherm and Yang 1996; Weems et al. 2015). However it would be interesting to test whether treatment effect on root rot during the mid- or late reproductive stages is correlated more closely with foliar symptoms of SDS.

Fluopyram seed treatment reduced the seedling population in Highgate, $\mathrm{ON}$ in 2014 as compared with the base seed treatment. Meta-analysis showed $2.2 \%$ overall reduction by fluopyram seed treatment. The reduction in plant population could be linked to the phytotoxicity that fluopyram causes on emerging seedlings. However, the reduction did not affect yield, likely because the soybean plant can adjust to available space and produce adequate yield despite a reduction in plant population (Board 2000; Carpenter and Board 1997).

Although farmers now have another management tool available to help reduce SDS severity, this research indicates that SDS still cannot be managed with a single tool alone. Based on our research, we

Table 8. Correlation among disease variables and yield observed in 11 field experiments carried out in four states in the United States and in Ontario, Canada during 2013 and 2014

\begin{tabular}{|c|c|c|c|c|c|c|c|c|c|c|c|}
\hline \multirow[b]{3}{*}{ Factor $^{\mathbf{Z}}$} & \multicolumn{11}{|c|}{ Correlation coefficient $(P>r)^{\mathrm{y}}$} \\
\hline & \multicolumn{5}{|c|}{2013} & \multicolumn{6}{|c|}{2014} \\
\hline & Bo & Ur & De & $\mathbf{H g}$ & Rd & Am & $\mathbf{U r}$ & Wa & De & $\mathrm{Hg}$ & Rd \\
\hline FDX - Yield & $\begin{array}{c}\text { NT } \\
\ldots\end{array}$ & $\begin{array}{c}-0.84 \\
(<0.01)\end{array}$ & $\begin{array}{c}-0.52 \\
(<0.01)\end{array}$ & $\begin{array}{c}-0.15 \\
(0.14)\end{array}$ & $\begin{array}{c}-0.21 \\
(0.03)\end{array}$ & $\begin{array}{l}-0.36 \\
(<0.01)\end{array}$ & $\begin{array}{c}-0.30 \\
(0.01)\end{array}$ & $\begin{array}{c}-0.40 \\
(<0.01)\end{array}$ & $\begin{array}{c}-0.39 \\
(<0.01)\end{array}$ & $\begin{array}{c}-0.95 \\
(<0.01)\end{array}$ & $\begin{array}{c}-0.63 \\
(<0.01)\end{array}$ \\
\hline FDX - RR & $\begin{array}{c}-0.38 \\
(0.03)\end{array}$ & $\begin{array}{c}0.31 \\
(0.09)\end{array}$ & $\begin{array}{c}0.22 \\
(0.22)\end{array}$ & $\begin{array}{l}\ldots \\
\ldots\end{array}$ & $\begin{array}{l}\ldots \\
\ldots\end{array}$ & $\begin{array}{c}-0.28 \\
(0.07)\end{array}$ & $\begin{array}{l}\ldots \\
\ldots\end{array}$ & $\begin{array}{c}-0.03 \\
(0.85)\end{array}$ & $\begin{array}{c}0.21 \\
(0.20)\end{array}$ & $\begin{array}{l}\ldots \\
\ldots\end{array}$ & $\begin{array}{l}\ldots \\
\ldots\end{array}$ \\
\hline FDX - Fv DNA & $\begin{array}{c}-0.01 \\
(0.95)\end{array}$ & $\begin{array}{c}0.32 \\
(0.08)\end{array}$ & $\begin{array}{l}\ldots \\
\ldots\end{array}$ & $\begin{array}{c}0.37 \\
(0.04)\end{array}$ & $\begin{array}{c}0.52 \\
(0.00)\end{array}$ & $\begin{array}{c}-0.27 \\
(0.10)\end{array}$ & $\begin{array}{l}\ldots \\
\ldots\end{array}$ & $\begin{array}{c}0.24 \\
(0.16)\end{array}$ & $\begin{array}{c}0.17 \\
(0.30)\end{array}$ & $\begin{array}{c}0.16 \\
(0.34)\end{array}$ & $\begin{array}{c}-0.11 \\
(0.49)\end{array}$ \\
\hline RR - Yield & $\ldots$ & $\begin{array}{c}-0.26 \\
(0.16)\end{array}$ & $\begin{array}{c}-0.28 \\
(0.12)\end{array}$ & $\begin{array}{l}\ldots \\
\ldots\end{array}$ & $\begin{array}{l}\ldots \\
\ldots\end{array}$ & $\begin{array}{c}0.15 \\
(0.33)\end{array}$ & $\begin{array}{l}\ldots \\
\ldots\end{array}$ & $\begin{array}{c}0.04 \\
(0.80)\end{array}$ & $\begin{array}{c}-0.31 \\
(0.05)\end{array}$ & $\begin{array}{l}\ldots \\
\ldots\end{array}$ & $\begin{array}{l}\ldots \\
\ldots\end{array}$ \\
\hline
\end{tabular}

y Locations: Bo = Boone Iowa; Ur = Urbana, IL; De = Decatur, MI; Hg = Highgate, ON; Rd = Rodney, ON; Am = Ames, IA; and Wa = Wanatah, IN. NT = not tested. Foliar sudden death syndrome (SDS) was not observed in Lafayette, IN in 2013; thus, it was not included in the analysis. Numbers in parenthesis are $P>r$ values.

${ }^{z}$ FDX of SDS was calculated using the formula FDX $=$ FDI $\times$ FDS/9. Disease incidence (FDI) was estimated as percentage of symptomatic plants per plot and foliar SDS severity (FDS) was scored on a 0 -to- 9 scale $(0=$ no disease and $9=$ premature death $)$ based on percentage of the chlorotic and necrotic leaf area and defoliation. Root rot severity (RR), Fusarium virguliforme DNA concentration in root (Fv DNA), and grain yield were recorded in 6, 10, and 11 of 12 experiments conducted, respectively.

Table 9. Effect sizes, the differences between the fungicide treatments and base seed treatment (control), and corresponding test statistics for fluopyram seed treatment (ST) and in-furrow application (IF) made for sudden death syndrome (SDS) management in studies conducted in Illinois, Indiana, Iowa, and Michigan in the United States and in Ontario, Canada in 2013 and 2014, based on random effect multivariate meta-analysis

\begin{tabular}{|c|c|c|c|c|c|c|c|c|c|}
\hline \multirow[b]{2}{*}{ Response $^{\mathbf{v}}$} & \multirow[b]{2}{*}{ Treatment $^{\mathrm{w}}$} & \multirow[b]{2}{*}{$K^{x}$} & \multicolumn{4}{|c|}{ Effect size $^{u}$} & \multirow[b]{2}{*}{$P$ value } & \multirow[b]{2}{*}{ Control mean ${ }^{y}$} & \multirow[b]{2}{*}{$\operatorname{Diff}(\%)^{\mathbf{z}}$} \\
\hline & & & $\bar{D}$ & se $\bar{D}$ & $C I_{L}$ & $C \boldsymbol{I}_{U}$ & & & \\
\hline \multirow[t]{2}{*}{ Population (plants/ha) } & Fluopyram ST & 24 & $-7,689.1$ & $3,602.9$ & $-14,750.8$ & -627.4 & 0.04 & $356,975.0$ & -2.2 \\
\hline & Fluopyram IF & 24 & $-3,412.1$ & $3,602.9$ & $-10,473.8$ & $3,649.6$ & 0.35 & $356,975.0$ & -1.0 \\
\hline \multirow[t]{2}{*}{ Root rot $(\%)$} & Fluopyram ST & 12 & -1.3 & 0.60 & -2.5 & -0.1 & 0.04 & 17.9 & -7.3 \\
\hline & Fluopyram IF & 12 & -0.1 & 0.60 & -1.3 & 1.1 & 0.88 & 17.9 & -0.6 \\
\hline \multirow[t]{2}{*}{ DNA (fg/ng) } & Fluopyram ST & 20 & -0.58 & 0.41 & -1.38 & 0.22 & 0.16 & 22.49 & -2.6 \\
\hline & Fluopyram IF & 20 & 0.15 & 0.41 & -0.65 & 0.96 & 0.71 & 22.49 & 0.7 \\
\hline \multirow[t]{2}{*}{ FDX } & Fluopyram ST & 22 & -5.8 & 1.58 & -8.9 & -2.7 & $<0.01$ & 14.1 & -41.1 \\
\hline & Fluopyram IF & 22 & -4.2 & 1.58 & -7.3 & -1.1 & 0.01 & 14.1 & -29.8 \\
\hline \multirow[t]{2}{*}{ Yield (kg/ha) } & Fluopyram ST & 22 & 193.2 & 66.2 & 63.5 & 322.9 & $<0.01$ & $3,481.2$ & 5.5 \\
\hline & Fluopyram IF & 22 & 142.3 & 66.2 & 12.5 & 272.0 & 0.03 & $3,481.2$ & 4.1 \\
\hline
\end{tabular}

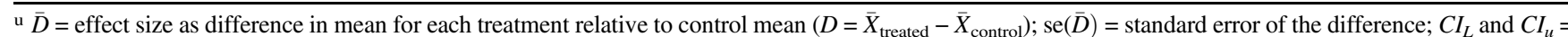
lower and upper limits, respectively, of the $95 \%$ confidence interval of the mean difference $\left(C I 95 \%(e f f e c t)=e f f e c t \pm 1.96 \times S E_{\text {effect }}\right)$; and $P=\operatorname{significance~level}$ of the effect size for each treatment.

$\checkmark$ DNA $=$ Fusarium virguliforme DNA per total DNA. FDX $=$ foliar disease index, calculated by using the formula FDI $\times$ FDS/9. Disease incidence $($ FDI) was estimated as percentage of symptomatic plants per plot and foliar SDS severity (FDS) was scored on a 0 -to- 9 scale $(0=$ no disease and $9=$ premature death) based on percentage of the chlorotic and necrotic leaf area and defoliation.

${ }^{w}$ Fluopyram (ILeVO and Luna Privilege, Bayer CropScience); ILeVO was used in seed treatment at $0.15 \mathrm{mg}$ a.i./seed and Luna Privilege was used for in-furrow application at $0.23 \mathrm{~kg} / \mathrm{ha}$.

x $K=$ total number of studies used in the analysis.

${ }^{y}$ Least square means of the base treatment for FDX and yield as estimated by meta-analysis.

z Percent difference was calculated using the formula Percent difference $=\bar{D} /$ control mean $) \times 100$. 

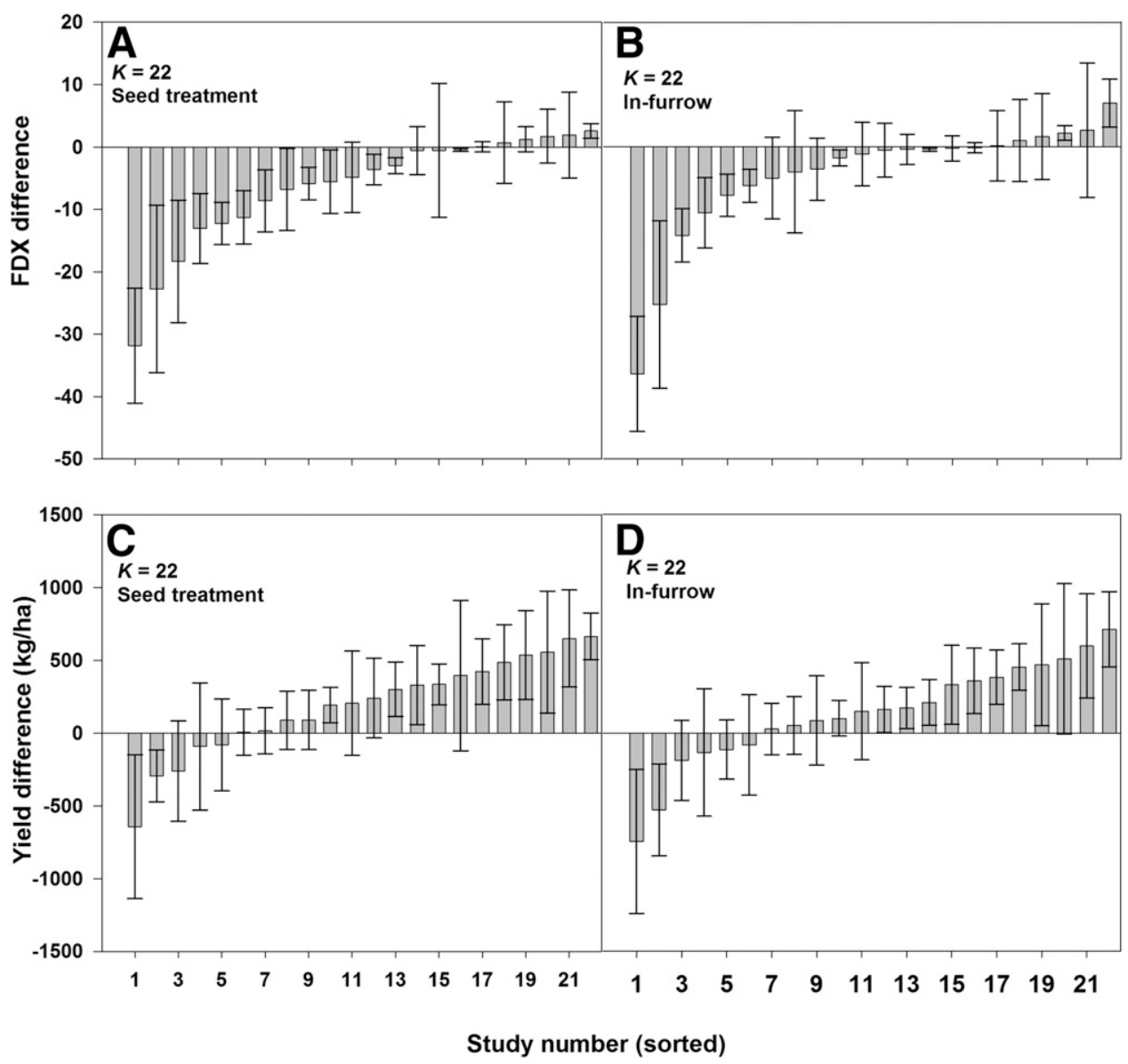

Fig. 1. Mean difference between fungicide treatments and the control (base seed treatment), sorted from the lowest to highest for foliar disease index (FDX) and yield (kg/ha). A, FDX difference between fluopyram seed treatment and the control; B, FDX difference between fluopyram in-furrow application and the control; C, yield difference between fluopyram seed treatment and the control; and $\mathrm{D}$, yield difference between fluopyram in-furrow application and the control. Each bar represents the difference $\left(D=\bar{X}_{\text {treated }}-\bar{X}_{\text {control }}\right)$ averaged across four replications, and the vertical lines extending from the bar represent standard error of the difference. $K$ is the number of studies used in the analysis. Experiments were conducted in Illinois, Indiana, lowa, and Michigan in the United States and Ontario in Canada in 2013 and 2014.

Table 10. Effect sizes, the difference between fungicide treatments and control (base seed treatment) as influenced by disease level in control plots, and corresponding statistics for fluopyram seed treatment (ST) and in-furrow application (IF) made for sudden death syndrome (SDS) management in field experiments performed in Illinois, Indiana, Iowa, Michigan in the United States and in Ontario, Canada in 2013 and 2014, based on random effect multivariate meta-analysis using disease level as a moderate variable

\begin{tabular}{|c|c|c|c|c|c|c|c|c|c|}
\hline \multirow[b]{2}{*}{ Resp, Trt $^{\mathbf{v}}$} & \multirow[b]{2}{*}{ Disease $^{w}$} & \multirow[b]{2}{*}{$K^{\mathbf{x}}$} & \multicolumn{5}{|c|}{ Effect size $^{\mathbf{u}}$} & \multirow[b]{2}{*}{ Controly $^{\mathbf{y}}$} & \multirow[b]{2}{*}{$\operatorname{Diff}(\%)^{\mathrm{z}}$} \\
\hline & & & $\bar{D}$ & se $\bar{D}$ & $C I_{L}$ & $C I_{U}$ & $P$ & & \\
\hline \multicolumn{10}{|l|}{ FDX } \\
\hline \multirow[t]{2}{*}{ Fluo ST } & Low & 11 & -1.8 & 1.71 & -5.1 & 1.6 & 0.30 & 4.2 & -41.9 \\
\hline & High & 11 & -10.4 & 1.93 & -14.2 & -6.7 & $<0.01$ & 25.0 & -41.7 \\
\hline \multirow[t]{2}{*}{ Fluo IF } & Low & 11 & -0.1 & 1.71 & -3.5 & 3.2 & 0.95 & 4.2 & -2.7 \\
\hline & High & 11 & -8.9 & 1.93 & -12.7 & -5.1 & $<0.01$ & 25.0 & -35.6 \\
\hline \multicolumn{10}{|l|}{ Yield } \\
\hline \multirow[t]{2}{*}{ Fluo ST } & Low & 10 & 68.0 & 111.6 & -150.6 & 286.7 & 0.54 & 3634.5 & 1.9 \\
\hline & High & 10 & 342.8 & 100.2 & 146.4 & 539.1 & $<0.01$ & 3252.4 & 10.5 \\
\hline \multirow[t]{2}{*}{ Fluo IF } & Low & 10 & -83.4 & 111.6 & -302.1 & 135.2 & 0.46 & 3634.5 & -2.3 \\
\hline & High & 10 & 338.8 & 100.2 & 142.4 & 535.2 & $<0.01$ & 3252.4 & 10.4 \\
\hline
\end{tabular}

u $\bar{D}=$ effect size as difference in mean for each treatment relative to control mean $\left(D=\bar{X}_{\text {treated }}-\bar{X}_{\text {control }}\right) ; \operatorname{se}(\bar{D})=$ standard error of the difference; $C I_{L}$ and $C I_{u}=$ lower and upper limits, respectively, of the $95 \%$ confidence interval of the mean difference $\left(C 195 \%(\right.$ effect $)=$ effect $\left.\pm 1.96 \times S E_{\text {effect }}\right)$; and $P=$ significance level of the effect size for each treatment

$\vee$ Response and treatment. FDX $=$ foliar disease index, calculated by using the formula FDI $\times$ FDS/9. Disease incidence (FDI) was estimated as percentage of symptomatic plants per plot and foliar SDS severity (FDS) was scored on a 0 -to- 9 scale $(0=$ no disease and $9=$ premature death $)$ based on percentage of the chlorotic and necrotic leaf area and defoliation. Fluopyram (Fluo) (ILeVO and Luna Privilege; Bayer CropScience); ILeVO was used in seed treatment at $0.15 \mathrm{mg}$ a.i./seed and Luna Privilege was used for in-furrow application at $0.23 \mathrm{~kg} / \mathrm{ha}$.

${ }^{\mathrm{w}}$ Base disease in control plots categorized as low (<10 FDX) and high (>10 FDX).

${ }^{\mathrm{x}} K=$ total number of studies used in the analysis.

${ }^{y}$ Control mean: least square means of the base seed treatment for FDX and yield as estimated by meta-analysis

${ }^{\mathrm{z}}$ Percent difference was calculated using the formula Percent difference $=\bar{D} /$ control mean $) \times 100$. 
suggest that fluopyram be used in conjunction with resistant cultivars and in areas with a history of SDS and where soybean would be at greatest risk for disease development, such as compacted soils, early planting, SCN presence, and so on. It is important that farmers understand that fluopyram is an added expense to soybean production, and our research suggests that even with SDS risk factors present, disease may not develop to a level that reduces yield, thereby reducing the economic benefit of the fungicide seed treatment. The research presented here will help farmers make informed decisions about SDS management and also serve as a foundation for future studies regarding integrated management of SDS.

\section{Acknowledgments}

The study was funded by Bayer CropScience and soybean checkoff programs through the North Central Soybean Research Program in the United States and The Grain Farmers of Ontario, Canada, which obtained funding through the Ontario Farm Innovation Program, which is a component of Growing Forward. We thank S. Wiggs from Iowa State University; A. M. Byrne and J. L. Jacobs from Michigan State University; N. Anderson, J. Leuck, and J. Ravellette from Purdue University; K. Ames and J. Weems from the University of Illinois; and C. Van Herk and G. Kotulak from the Ontario Ministry of Agriculture, Food, and Rural Affairs for technical support; and J. Batzer for reviewing this manuscript.

\section{Literature Cited}

Anderson, T., and Tenuta, A. 1998. First report of Fusarium solani f. sp. glycines causing sudden death syndrome of soybean in Canada. Plant Dis. 82:448.

Aoki, T., O'Donnell, K., Homma, Y., and Lattanzi, A. R. 2003. Sudden death syndrome of soybean is caused by two morphologically and phylogenetically distinct species within the Fusarium solani species complex $-F$. virguliforme in North America and F. tucumaniae in South America. Mycologia 95: 660-684.

Board, J. 2000. Light interception efficiency and light quality affect yield compensation of soybean at low plant populations. Crop Sci. 40:1285-1294.

Bradley, C. A., Allen, T., and Esker, P. 2014. Estimates of soybean yield reductions caused by diseases in the United States. Online publication. Extension and Outreach, Department of Crop Sciences, University of Illinois. http://extension.cropsciences.illinois.edu/fieldcrops/diseases/yield_ reductions.php

Brar, H. K., Swaminathan, S., and Bhattacharyya, M. K. 2011. The Fusarium virguliforme toxin FvTox1 causes foliar sudden death syndrome-like symptoms in soybean. Mol. Plant-Microbe Interact. 24:1179-1188.

Carpenter, A. C., and Board, J. E. 1997. Branch yield components controlling soybean yield stability across plant populations. Crop Sci. 37:885-891.

Chala, A., Weinert, J., and Wolf, G. A. 2003. An integrated approach to the evaluation of the efficacy of fungicides against Fusarium culmorum, the cause of head blight of wheat. J. Phytopathol. 151:673-678.

de Farias Neto, A. L., Hartman, G. L., Pedersen, W. L., Li, S., Bollero, G. A., and Diers, B. W. 2006. Irrigation and inoculation treatments that increase the severity of soybean sudden death syndrome in the field. Crop Sci. 46: 2547-2554.

Ellis, M. L., Broders, K. D., Paul, P. A., and Dorrance, A. E. 2011. Infection of soybean seed by Fusarium graminearum and effect of seed treatments on disease under controlled conditions. Plant Dis. 95:401-407.

Fehr, W. R., Caviness, C. E., Burmood, D. T., and Pennington, J. S. 1971. Stage of development descriptions for soybeans, Glycine max (L.) Merrill. Crop Sci. 11: 929-931.

Fought, L., Musson, G. H., and Young, H. 2011. Fluopyram fungicides for the control of diseases of horticultural and row crops. (Abstr.) Phytopathology. 101:S54

Gibson, P., Shenaut, M., Njiti, V., Suttner, R., and Myers, O., Jr. 1994. Soybean varietal response to sudden death syndrome. Pages 20-40 in: Proc. 24th Soybean Seed Res. Conf. Chicago. D. Wilkinson, ed. American Seed Trade Association, Washington, DC.

Guy, S. O., Oplinger, E. S., and Grau, C. R. 1989. Soybean cultivar response to metalaxyl applied in-furrow and as a seed treatment. Agron. J. 81:529-532.

Hartman, G. L., Chang, H. X., and Leandro, L. F. 2015a. Research advances and management of soybean sudden death syndrome. Crop Prot. 73:60-66.

Hartman, G. L., Leandro, L. F. S., and Rupe, J. C. 2015b. Sudden death syndrome. Pages 88-90 in: Compendium of Soybean Diseases and Pests. G. L. Hartman, J. C. Rupe, E. F. Sikora, L. L. Domier, J. A. Davis, and K. L. Steffey, eds. American Phytopathological Society, St. Paul, MN.

Hershman, D., Hendrix, J., Stuckey, R., Bachi, P., and Henson, G. 1990. Influence of planting date and cultivar on soybean sudden death syndrome in Kentucky. Plant Dis. 74:761-766

Hirrel, M. C. 1983. Sudden death syndrome of soybean-A disease of unknown etiology. (Abstr.) Phytopathology 73:501.

Kandel, Y. R., Bradley, C. A., Wise, K. A., Chilvers, M. I., Tenuta, A. U., Davis, V. M., Esker, P. D., Smith, D. L., Licht, M. A., and Mueller, D. S. 2015. Effect of glyphosate application on sudden death syndrome of glyphosate-resistant soybean under field conditions. Plant Dis. 99:347-354.
Koenning, S. R., and Wrather, J. A. 2010. Suppression of soybean yield potential in the continental United States by plant diseases from 2006 to 2009 . Online publication. Plant Health Prog. doi:10.1094/PHP-2010-1122-01-RS

Kolander, T. M., Bienapfl, J. C., Kurle, J. E., and Malvick, D. K. 2012 Symptomatic and asymptomatic host range of Fusarium virguliforme, the causal agent of soybean sudden death syndrome. Plant Dis. 96:1148-1153.

Labourdette, G., Lachaise, H., Rieck, H., and Steiger, D. 2010. Fluopyram: A new antifungal agent for the control of problematic plant diseases of many crops. Julius-Kuhn-Archiv. 428:91-92.

Leandro, L. F., Tatalovic, N., and Luckew, A. 2012. Soybean sudden death syndrome - advances in knowledge and disease management. CAB Rev. 7:1-14

Leandro, L. F. S., Robertson, A. E., Mueller, D. S., and Yang, X. B. 2013. Climatic and environmental trends observed during epidemic and non-epidemic years of sudden death syndrome in Iowa. Online publication. Plant Health Prog. doi: 10.1094/PHP-2013-529-01-RS

Luo, Y., Hildebrand, K., Chong, S., Myers, O., and Russin, J. 2000. Soybean yield loss to sudden death syndrome in relation to symptom expression and root colonization by Fusarium solani f. sp. glycines. Plant Dis. 84:914-920.

Madden, L. V., and Paul, P. A. 2011. Meta-analysis for evidence synthesis in plant pathology: An overview. Phytopathology 101:16-30.

Meredith, R. H. 2012. Control of fruit rots and foliar diseases in soft fruit, using a new fungicide product based on fluopyram and trifloxystrobin. Asp. Appl. Biol. 117:241-248.

Mueller, D. S., Nelson, R. L., Hartman, G. L., and Pedersen, W. L. 2003. Response of commercially developed soybean cultivars and the ancestral lines to Fusarium solani f. sp. glycines. Plant Dis. 87:827-831.

Mueller, D. S., Wise, K. A., Dufault, N. S., Bradley, C. A., and Chilvers, M. A., eds. 2013. Fungicides for Field Crops. American Phytopathological Society, St. Paul, MN.

Njiti, V. N., Shenaut, M. A., Suttner, R. J., Schmidt, M. E., and Gibson, P. T. 1998 Relationship between soybean sudden death syndrome disease measures and yield components in F6-derived lines. Crop Sci. 38:673-678.

Paul, P. A., Hershman, D. E., McMullen, M. P., Draper, M. A., and Madden, L. V. 2008. Efficacy of triazole-based fungicides for Fusarium head blight and deoxynivalenol control in wheat: A multivariate meta-analysis. Phytopathology 98:999-1011.

Piepho H. P. 2014. Network-meta analysis made easy: Detection of inconsistency using factorial analysis-of-variance models. Online publication. BMC Med. Res. Methodol. 14:61.

Piepho, H. P., Williams, E. R., and Madden, L. V. 2012. The use of two-way linear mixed models in multitreatment meta-analysis. Biometrics 68:1269-1277.

Proffer, T. J., Lizotte, E., Rothwell, N. L., and Sundin, G. W. 2013. Evaluation of dodine, fluopyram and penthiopyrad for the management of leaf spot and powdery mildew of tart cherry, and fungicide sensitivity screening of Michigan populations of Blumeriella jaapii. Pest Manage. Sci. 69:747-754.

Pudake, R. N., Swaminathan, S., Sahu, B. B., Leandro, L. F., and Bhattacharyya, M. K. 2013. Investigation of the Fusarium virguliforme fvtoxl mutants revealed that the FvTox 1 toxin is involved in foliar sudden death syndrome development in soybean. Curr. Genet. 59:107-117.

Roy, K., Hershman, D., Rupe, J., and Abney, T. 1997. Sudden death syndrome of soybean. Plant Dis. 81:1100-1111.

Rupe, J. C., Robbins, R. T., and Gbur, E. E., Jr. 1997. Effect of crop rotation on soil population densities of Fusarium solani and Heterodera glycines and on the development of sudden death syndrome of soybean. Crop Prot. 16: 575-580.

Rupe, J. C., Sabbe, W. E., Robbins, R. T., and Gbur, E. E. 1993. Soil and plant factors associated with sudden death syndrome of soybean. J. Prod. Agric. 6: 218-221.

Scherm, H. and Yang, X. 1996. Development of sudden death syndrome of soybean in relation to soil temperature and soil water matric potential. Phytopathology 86:642-649.

Scherm, H., and Yang, X. 1999. Risk assessment for sudden death syndrome of soybean in the north-central United States. Agric. Syst. 59:301-310.

Scherm, H., Yang, X., and Lundeen, P. 1998. Soil variables associated with sudden death syndrome in soybean fields in Iowa. Plant Dis. 82:1152-1157.

Smith, J., Grimmer, M., Waterhouse, S., and Paveley, N. 2013. Quantifying the non-fungicidal effects of foliar applications of fluxapyroxad (Xemium) on stomatal conductance, water use efficiency and yield in winter wheat. Commun. Agric. Appl. Biol. Sci. 78:523-535.

Stephens, P. A., Nickell, C. D., and Lim, S. M. 1993a. Sudden death syndrome development in soybean cultivars differing in resistance to Fusarium solani. Crop Sci. 33:63-66.

Stephens, P. A., Nickell, C. D., Moots, C. K., and Lim, S. M. 1993b. Relationship between field and greenhouse reactions of soybean to Fusarium solani. Plan Dis. 77:163-166.

Veloukas, T., and Karaoglanidis, G. S. 2012. Biological activity of the succinate dehydrogenase inhibitor fluopyram against Botrytis cinerea and funga baseline sensitivity. Pest Manage. Sci. 68:858-864.

Wang, J., Jacobs, J. L., Byrne, J. M., and Chilvers, M. I. 2015. Improved diagnoses and quantification of Fusarium virguliforme, causal agent of soybean sudden death syndrome. Phytopathology 105:378-387.

Weems, J. D., Haudenshield, J. S., Bond, J. P., Hartman, G. L., Ames, K. A., and Bradley, C. A. 2015. Effect of fungicide seed treatments on Fusarium 
virguliforme infection of soybean and development of sudden death syndrome. Can. J. Plant Pathol. 37:435-447.

Westphal, A., Li, C., Xing, L., McKay, A., and Malvick, D. 2014. Contributions of Fusarium virguliforme and Heterodera glycines to the disease complex of sudden death syndrome of soybean. PLoS One 9:e99529.

Wrather, J., Kendig, S., Anand, S., Niblack, T., and Smith, G. 1995. Effects of tillage, cultivar, and planting date on percentage of soybean leaves with symptoms of sudden death syndrome. Plant Dis. 79:560-562.

Wrather, J. A., and Koenning, S. R. 2006. Estimates of disease effects on soybean yields in the United States 2003 to 2005. J. Nematol. 38:173-180.

Wrather, J. A., Shannon, G., Balardin, R., Carregal, L., Escobar, R., Gupta, G. K., Ma, Z., Morel, W., Pioper, D., and Tenuta, A. 2010. Effect of diseases on soybean yield in the top eight producing countries in 2006. Online publication. Plant Health Prog. doi:10.1094/PHP-2010-0125-01-RS

Xing, L., and Westphal, A. 2006. Interaction of Fusarium solani f. sp. glycines and Heterodera glycines in sudden death syndrome of soybean. Phytopathology 96 : 763-770.

Xing, L., and Westphal, A. 2009. Effects of crop rotation of soybean with corn on severity of sudden death syndrome and population densities of Heterodera glycines in naturally infested soil. Field Crops Res. 112:107-117.

Yoshida, M., Nakajima, T., Arai, M., Suzuki, F., and Tomimura, K. 2008. Effect of the timing of fungicide application on Fusarium head blight and mycotoxin accumulation in closed-flowering barley. Plant Dis. 92: 1164-1170. 